\title{
Fama y verdad en la épica quinientista española. El virgilianismo político y la tradición castellana del siglo xv
}

\author{
Lara Vilà \\ Universitat de Girona \\ lara.vila@udg.edu
}

Fecha de recepción: 27/04/2010, Fecha de publicación: 18/05/2010

<URL: http://www.studiaaurea.com/articulo.php?id=129>

\begin{abstract}
Resumen
Este estudio propone una aproximación a la lectura del corpus épico quinientista a la luz de consideraciones históricas y de la propia tradición literaria hispana del Cuatrocientos. En concreto, postula que la épica debe pensarse desde presuposiciones teóricas e indaga la relación del género con la historia para iluminar las diferencias existentes entre la teoría y la práctica épicas en la Península Ibérica e Italia en el siglo xvi. Dicha relación descansa no sólo en la apropiación del modelo virgiliano y su mitificación de la historia reciente sino que debe buscarse, también, en los distintos usos de la literatura clásica por parte de los humanistas italianos y los intelectuales castellanos del siglo Xv. En particular, el artículo considera la pertinencia de atenerse, para la configuración de la idea de la épica en la Espańa del Quinientos, a los dictados de la tradición épica occidental desde una perspectiva específicamente hispana, amparada en un "virgilianismo político» que ya encontramos alumbrado en autores como Enrique de Villena y Juan de Mena, que resulta fundamental para explicar la épica como memoria del presente.
\end{abstract}

Palabras clave

alegoría, Enrique de Villena, épica, historia, Juan de Mena, Virgilio.

\begin{abstract}
Fame and truth in Spanish XVth century epic. The political vergilianism and the castilian tradition of the Xvth century

The starting premise of this essay is that the Spanish Golden Age epic must be read from a historical perspective that takes into account the Hispanic literary tradition of the xvth century. In particular, it argues that epic should be approached from a theoretical perspective that explores its relationship with history in order to illuminate the differences between Italian and Spanish epic theory and practice in the xvith century. The relationship between the discourses of epic and history can be explained through the imitation of the Vergilian model, specifically the Aeneid's ideological representation of empire. However, it is also necessary to consider theoretical aspects in the light of the
\end{abstract}


different uses of classical literature by Italian humanists and Castilian writers of the xvth century. Thus, its primary thesis is that although xvith century Spanish epic shares the general principles of the Western Epic tradition, it should be approached from a specifically perspective Hispanic, in the light of the "political vergilianism» already enshrined in authors like Enrique de Villena and Juan de Mena, which is essential to appreciate how epic genre serves as memory for the present.

\section{Key words}

allegory, Enrique de Villena, epic, history, Juan de Mena, Vergil.

El mundo debajo de tanta verdad vea lo que por ficiones admira

Diego Jiménez de Ayllón, El Cid

Las palabras de Diego Jiménez de Ayllón arriba citadas compendian una idea que reencontramos, aquí y allá, en otros muchos prólogos, cartas y dedicatorias de los poemas épicos del Quinientos español. La machacona insistencia con que los autores españoles afirman que escriben una épica de la verdad se inscribe y se explica desde una mentalidad eminentemente bélica e imperial, destinada a la lectura de monarcas, nobles y caballeros, que reconocen en la poesía épica una forma de historia, embellecida sin duda, pero, como tal, con un indudable valor ejemplar. La épica, al cabo, deviene una forma más de servicio a la corona y a la patria, y, por ello, no cabe remontarse a heroicidades antiguas: el presente ofrece innumerables casos dignos de ser presentados en el marco del género mayor en excelencia y el que mejor representa a la monarquía y a sus élites.

Esta concepción de la épica como género gremial, «del nuevo cuerpo político imperial», en palabras de Elizabeth Davis, ${ }^{1}$ y como forma alternativa de una historia empeñada en remediar del olvido las gestas de los nuevos héroes nacionales, como ha estudiado espléndidamente María José Vega, ${ }^{2}$ contrasta no sólo con lo que, en fechas similares, se propugna desde las filas del neoaristotelismo italiano: a la vez, constituye el modo particular en que la Espańa imperial de los Austrias Mayores entiende e hispaniza la escritura épica. Sin embargo, el núcleo de la composición épica del Renacimiento, su historicidad, ha sido la responsable de

1. Vid. Davis (2005: 331). Al respecto, véase también Davis (2001).

2. Vid. Vega (2010). 
que buena parte de los críticos decimonónicos y de principios del siglo siguiente haya menospreciado a la épica española por su servilidad hacia la historia ${ }^{3}$ o hayan dudado incluso de que tal cosa exista, ${ }^{4}$ a pesar de algunas voces que, atinadamente, ya insistían en conceder a esta historicidad la importancia que sin duda merece para la comprensión plena del corpus, relacionándola con la realidad política de la España del momento. 5 Pasarían todavía algunos años, sin embargo, para que esta visión negativa, herencia indudable de un sentir que concebía a la lírica como el género más representativo e importante del período renacentista en España, se viera relativizada, especialmente a partir de los estudios de Frank Pierce y Maxime Chevalier, que insistían en presentar la épica culta española a la luz de los sucesos históricos contemporáneos. ${ }^{6}$ Tras sus pasos, los críticos poste-

3. Véase la crítica de Menéndez Pelayo (194647). En la edición de sus Obras completas, Quintana (1946: 159) señala como «principio de error» el hecho de que «Quisieron nuestros épicos tener el crédito de historiadores, y al mismo tiempo el halago y aplauso de poetas: mezclaron la fábula con la verdad, no fundiéndolas agradablemente (...) y creyeron que contando hazañas grandes, coetáneas, ruidosas entonces tanto en el mundo, y contándolas en el verso que se llamaba heroico, ya podían creerse autores de epopeya y decirse alumnos de Homero y de Virgilio».

4. Cayetano Rosell (1945: 1) sostenía que «Poema verdaderamente épico, ninguno existe en nuestra literatura». Y el mismo Quintana, op. cit., p. 158, sostenía que «son muy pocas las obras de esta clase dignas de atención y de memoria» y sancionaba lapidariamente que "la mayor parte de estas producciones, ya informes e indigestas, ya desaliñadas y frías, les niegan irremisiblemente el nombre de epopeyas.»

5. Cirot (1946: 319, 322) apuntaba ya que «L'épopée est une annexe de l'histoire, une forme de l'historiographie» y vinculaba esta característica a que "L'Espagne étatit en pleine effervescence de guerres et de conquêtes. Il y régnait une excitation morale qui s'est tout naturellement traduite par ces expansions débordantes, dont beaucoup procèdent plus de l'esprit d'un Lucain ou d'un Stace, que de celui d'un Pulci, d'un Boiardo, de l'Arioste ou du Tasse, quelle que soit la similitude de forme; sans compter l'influence directe ou non des poèmes homériques.» Asensio (1949: 84), en su revisión panorámica de los lazos que unen a la producción épica española y la portuguesa, distingue para la que llama «épica profana» tres bases narrativas: «el poema en que la historia o leyenda viste todas las galas de la fábula y la verdad se sacrifica a la fantasía; la crónica guerrera en que los atavíos mitológicos y novelescos se confinan a los episodios; y el poema encomiástico de bodas y entradas triunfales de reyes y grandes señores.» (Asensio incluye en el primero de estos tipos a la gran mayoría de poemas escritos a imitación de los romanzi italianos, si bien éstos no están exentos, tampoco, de una historización y actualización de los hechos contemporáneos.) Valbuena Briones (1958: 100-101), en su estudio de la Historia verdadera de la Conquista de la Nueva España de Bernal Díaz del Castillo alertaba de la necesidad de "revisión de la epopeya y su definición» y concedía que «la épica otorga a su país un certificado de nacionalidad, de conciencia de pueblo.»

6. Pierce (1968: 22) manifestaba que «la preferencia por los acontecimientos históricos recientes y la declarada intención de respetar la verdad histórica de toda época dan a la épica española un énfasis personal. (...) Esta preocupación por la historia puede verse como fase del culto poético a la gloria nacional y a las familias nobles y su heroica estirpe; así, puede alegarse que el epos tiene algo en común con la historiografía renacentista»; Chevalier (1966: 122), en su monografía sobre la influencia del Orlando Furioso en España, sostiene que el esfuerzo de los poetas épicos españoles del Quinientos «correspond à l'un des aspects d'une revendication nationale plus vaste. L'Espagne triomphante de CharlesQuint et de ses héritiers estime que les prouesses de ses conquistadors et de ses capitaines ont sur- 
riores apuntan a una consideración de la épica que tenga ante todo presente esta visión historicista y nacionalista del género, indefectiblemente vinculada con la dependencia de los grandes autores canónicos, antiguos y modernos. ${ }^{7}$

Sin ninguna duda, la historicidad y el carácter nacionalista de la épica quinientista española no pueden entenderse sin tener presente la preeminencia del modelo virgiliano ( $\mathrm{y}$ de sus continuadores), algo que he analizado extensamente en estudios anteriores, lo que me exime de referir aquí cómo los poetas épicos áureos proponen ante todo una reescritura interesada de la historia de la nación, al arrimo de la Eneida, con fines propagandísticos. ${ }^{8}$ Como he señalado en dichos estudios, la hispanización de Virgilio en la épica culta española obedece también a la propia dinámica de la tradición épica occidental, que ampara la integración de otros poemas épicos que aún obedeciendo a presuposiciones ideológicas que cuestionan las del modelo canónico pueden ser reconducidos como opciones igualmente autorizadas por razón de su dependencia formal y narrativa. Tal es el caso de Lucano, sentido por los poetas españoles, ya desde la generación de Juan de Mena, como un compatriota y como poeta de la historia reciente, pese a lo expuesto por Servio y, tras los pasos del comentarista, por no pocos preceptistas italianos del Quinientos. ${ }^{9}$ Es justamente esta «veracidad», este interés de los poetas épicos españoles por referir las hazañas de un presente considerado glorioso y digno de ser celebrado en el marco épico, ${ }^{10}$ uno de los aspectos que enfrentan

passé les plus fameux exemples de valeur que le monde a connus». Insiste también en que todos presentan su obra como un tributo a la memoria del héroe hispano Bernardo del Carpio y relaciona esta finalidad de la épica con la de la historiografía contemporánea ( $«$ A cet appel répond l'essor de l'historiograhie espagnole à la fin du $\mathrm{XV}^{\mathrm{e}}$ siècle et au début du siècle suivant, qui produira tant d'œuvres où apparaît le désir d'exalter la grandeur espagnole, définie comme supérieure à celle de Rome»). Y Chevalier (1976: 106, $111,119)$ restituye la importancia contemporánea del género y, tras postular la importante relación de la épica «con la vida literaria y cultural del siglo», relaciona su éxito "con el empuje del nacionalismo español del siglo xvI», al tiempo que propone el abandono de un estudio más «formalista» o "estético» de unos poemas "que halagaban la ideología guerrera de que participaban los hidalgos y caballeros del Siglo de Oro». 7. Caravaggi (1974: 136, 164) es quizá el primero en apuntar una revisión téorica del género desde presuposiciones historicistas cuando afirma que «La polemica rinascimentale sul poema epico è in ultima analisi reducibile al rapporto tra storia e poesia» y subraya que los poetas quinientistas defienden «una posizione di 'veridicità»; Prieto (1979: 211, 210) aducía el "caracter de historicidad de la gesta espańola» $y$, centrado en la recepción del canon de Ferrara, predica la "oposición nacionalista» que caracteriza a la escritura épica espańola. Más recientemente, véanse las páginas que ha dedicado a esta cuestión Lara Garrido (1999).

8. Vid. Vilà $\left(2001,2003,2005^{a}\right.$, 2005 ${ }^{b}, 2005^{c}$, 2006, 2008 y 2009).

9 Así lo reconoce también Avalle-Arce (2000: 19): «Lucano en su Farsalia elevó el pasado inmediato (...) a la categoría épica». Véase también al respecto lo afirmado por Cirot, vid. supra, n. 5 . 10. Que no se circunscribe únicamente a los poemas que escriben sobre materia del presente sino que se percibe también, por ejemplo, en las reescrituras españolas del Orlando Furioso y demás romanzi caballerescos (amén de en una de sus traducciones contemporáneas de mayor fortuna, la de Jerónimo de Urrea, de 1549). En su gran mayoría, los que he llamado «poemas ariostescos» (vid. Vilà, 2003) retoman la materia carolingia para inscribirla en el elogio de 
a la tradición épica hispana con las consideraciones impuestas por una preceptiva contemporánea excesivamente dependiente de la Poética aristotélica y de la opinión de los autores clásicos en materia de poesía. ${ }^{11}$ En este sentido, la épica que se escribe en la Espańa del Quinientos rehúye sistemáticamente diversos aspectos considerados fundantes para la tratadística neoaristotélica con el fin de favorecer una visión enaltecedora de la historia nacional, para cumplir antes con el planteamiento virgiliano de la historia mitificada que con la pretendida universalidad aristotélica de la poesía. ${ }^{12}$ Hay, pues, una divergencia evidente entre la tratadística italiana y el parecer expresado por los propios poetas españoles en prólogos, dedicatorias y cartas nuncupatorias: mientras que los primeros destierran la lectura política y nacionalista de la épica (fundamental ya desde Servio) a los márgenes de la teoría o la silencian por no hallarle acomodo en unos tratados claramente orientados a la consideración formal de la poesía, en España, poco prolija, por cierto, en textos de esta naturaleza, dicha lectura resulta evidente y definitoria de la práctica del género. Y, como cabía esperar, ésta es inherente a la idea de que la épica es, ante todo, una forma de historia y a la visión que los propios contemporáneos tienen de la historia presente e imperial de la Espańa austríaca, tan parecida a la que Virgilio cantara en la Eneida para Augusto.

La épica española del Quinientos, en resumidas cuentas, predica tanto en la propia escritura como en una teoría que cabe indagar en gran medida (por no decir casi exclusivamente) en los paratextos de los propios poemas, ${ }^{13}$ una visión

un caballero español, Bernardo del Carpio, y se presentan como un rescate del injusto olvido de un héroe emparentado con la monarquía y vencedor de los franceses, cuyas gestas se proponen como preludio del enfrentamiento de los Austrias con la Francia de los Valois, que constituiría uno de los capítulos más sangrientos de la historia moderna de Europa. Dice Nicolás Espinosa, por ejemplo, en la dedicatoria al Conde de Oliva que principia su poema $L a$ segunda parte del Orlando con el verdadero suceso de la famosa batalla de Roncesvalles (1557) que: «Siendo cantadas (muy ilustre señor) las hazañas de los Pares de Francia, por los famosos Conde Descandiano y Ludovico Ariosto, hinchiendo el mundo de sus heroicos hechos, y que estaban sepultados en el olvido nuestros Españoles, que a éstos y muchos más en la nombrada lid de Roncesvalles vencieron y sobraron me pareció causa justa para el sobrado atrevimiento mío...». (La cursiva es mía) Es preciso señalar, en este sentido, que las disputas entre Carlos V y Francisco I, que se librarían principalmente en la Lombardía, no implicarían sólo el uso de las armas sino que, conocedores ambos monarcas del valor de la palabra escrita y de la difusión propagandística de la imagen regia, darían pie a verdaderas «batallas» de papel. Parecida hispanización se detecta en los poemas de finales de siglo escritos a imitación de la Gerusalemme Liberata. Al respecto, véase Vilà (2008).

11. Para una revisión exhaustiva de esta cuestión véanse los estudios recogidos en Vega y Vilà (2010).

12. Vid. Vega (2010: 107): «no importan pues tanto las cuestiones neoaristotélicas, cuanto las necesidades políticas del imperio y la percepción de la existencia de una historia poetizable que ya es heroica antes de ser contada.»

13. Las únicas preceptivas castellanas que dio el siglo son el Arte poética en romance castellano (Alcalá de Henares, 1580) del portugués Miguel Sanches de Lima, y la Philosophia Antigua Poetica (Madrid, 1596) de Alonso López Pinciano. Ambas plantean una explicación del fenómeno literario inscrita en el esquema neoaristotélico y, a diferencia de lo que se de- 
del género desde presuposiciones historicistas, que es la que guía la reescritura de los grandes modelos antiguos y modernos. Esta dependencia de la relación historiográfica o, al cabo, el planteamiento de que la épica es una forma de historia embellecida, adornada con los recursos propios de la poesía, y que tanto disgustara a los críticos, se revela como la espina dorsal que permite entender cómo este género es considerado el más excelente desde antiguo y el que sirve para remediar el olvido en que han caído las gestas de los españoles (por la falta de escritores, como tantas veces leemos en los textos de los autores del cuatrocientos castellanos). Al mismo tiempo, el «virgilianismo político» de la épica española del Quinientos sólo se entiende, en un sentido más amplio, dentro de una consideración social, cultural y política. La épica no sólo es el género más cercano a la esfera del poder sino que, en el siglo Xvi, las dinastías reinantes en Europa, y muy particularmente los Habsburgo, basan su imagen pública en una reelaboración de las metáforas del poder acuñadas en la épica virgiliana. La razón de las notables diferencias en la concepción épica, por ejemplo, de una España imperial y de una Italia que carece de un presente heroico afín, se manifiestan, en gran medida, en la voluntad por parte de los poetas españoles de salvar el rigor histórico y en su renuencia a conjugar historia y ficción, por considerar a la segunda como una "engorrosa necesidad», ${ }^{14}$ mientras que el discurso teórico italiano, resumido y coronado por la obra de Torquato Tasso, que encauza la discusión del estatuto ficcional de la narración épica en el seno de la polémica de los romanzi, prima su salvaguarda sometida a la unidad de acción aristotélica, en una solución que, en definitiva, busca antes una conciliación con los dictados de las autoridades clásicas en materia de poética (y una revocación de una supuesta particularidad genérica de los poemas narrativos caballerescos inspirados en el poema de Ariosto) que una explicación del fenómeno épico contemporáneo y su finalidad propagandística.

\section{La épica culta quinientista y la tradición castellana cuatrocentista}

Es claro, a la luz de lo expuesto arriba, que las divergencias entre la producción épica hispana y la italiana así como la diversa idea que del género tienen los

duce de la lectura de los prólogos de los poemas épicos españoles, la teoría épica del Pincino se ampara más de cerca en la dictada por Escalígero, repite muchos de los principios expuestos por Torquato Tasso y no indaga las cuestiones que realmente explican la práctica del género en España (si bien ejemplificará ésta en su poema El Pelayo, Madrid, 1605). De lo expuesto hasta aquí se deduce, pues, la parcialidad de un enfoque teórico centrado de forma exclusiva en la consideración de la preceptiva y las artes poéticas, insuficientes, como habrá apreciado ya el lector a estas alturas, para explicar las ideas más extendidas sobre la poesía heroica que, en gran medida, depende antes de la tradición comentarista virgiliana y los comentarios morales. Sobre este particular véase Vilà (2010).

14. Vid. Vega (2010: 113). 
preceptistas neoaristotélicos y los poetas españoles es cuestión fundamental para entender la producción heroica de la España imperial. Al mismo tiempo que se imbrica en la tradición épica renacentista europea, el «virgilianismo político» de la épica espańola obedece también, como ya hemos visto, a razones culturales, políticas y de conciencia nacional. En este sentido, para indagar la historicidad de la épica culta española del Quinientos es preciso volver la vista atrás, a la tradición textual del siglo precedente, para comprender cabalmente tanto los motivos que impulsan la escritura de una épica verdadera o histórica como la justificación teórica de esta opción narrativa en los prólogos programáticos. Esta cuestión redunda asimismo en una reflexión sobre los modos de utilización de la literatura clásica, tan diversa en el humanismo italiano y en lo que la crítica llamó inicialmente "prehumanismo» o "prerrenacimiento", revisado posteriormente por Lawrance en su idea del «humanismo vernáculo» castellano del siglo $\mathrm{xv} .{ }^{15} \mathrm{Si}$ algo puede definir certeramente la épica hispana del Quinientos es la libertad con que los poetas reflexionan sobre su escritura, que, ante todo, les lleva a proponer que la poesía heroica es un género moral y ejemplarizante (como la Historia) destinado a la lectura de determinados estamentos de la sociedad (monarca, nobles y caballeros, así como del estamento militar en general). ${ }^{16} \mathrm{Se}$

15. El tema ha sido estudiado tan extensamente que resulta imposible referenciar aquí la rica y numerosa bibliografía que se ocupa de él: entre los estudios clásicos remito a Lida (1950), Di Camillo (1976) y Rico (1983). Véanse también las páginas de Lawrance (1986, 1985 y 1990) y Gómez Moreno (1994). A lo largo de las páginas que siguen se indicarán otras referencias sobre diversos aspectos particulares.

16. Capítulo aparte merecería la consideración de la también abundante épica de tema sacro, que es, ante todo, obra de humanistas para humanistas. Un indicio claro de que estamos ante una rama más especializada de la épica culta se deduce del hecho que los títulos más importantes fueron escritos en latín (al arrimo de los poemas de Prudencio, Juvenco y Sedulio) y que éstos llenaban los anaqueles de los humanistas: en la biblioteca de Antonio Agustín, por ejemplo, encontramos, entre las obras contemporáneas, la célebre Talichristia (1525) y el De militia principis de Burgundi (1541) de Alvar Gómez de Ciudad Real, el De partu Virginis de Sannazaro (1526), incluido también en otro volumen colectáneo que edita también la Christias de Vida (posiblemente el Pii, graves, atque elegantes poetae aliquot, editado en Basi- lea en 1550 por Johann Oporinus), el Parthenice Mariana de Baptista Spagnuoli comentado por Badio Ascensio (1528) y los Poemata sacra de Laevinius Torrentius de 1572 (entre los que se incluye, por cierto, un In Ioannis Austriaci naualem de Turcos victoriam). Entre los poemas de la tarda clasicidad destacan, además de la colectánea de Poetae Christiani Veteres de Aldo Manuzio (1501), la Evangelicae Historia de Juvenco, las Opera de Prudencio con comentarios de Nebrija, además de un ejemplar exento de la Psychomachia de 1564 y una colectánea más con las obras de Juvenco, Sedulio y Arator. Es de señalar también la presencia de los comentarios alegóricos de Landino a la obra virgiliana, las Disputationes Camaldulenses. Sobre la biblioteca de Agustín véase Alcina y Salvadó (2007). Por su parte, como ha estudiado Vega (2010), la épica en vulgar de tema histórico compartía lugar, en las bibliotecas nobiliarias, con los volúmenes de historia. Recuérdese también, y es cuestión importante, que el primero de nuestros humanistas tout court, Antonio de Nebrija, escribió los comentarios más influyentes del siglo a la obra de Prudencio y Sedulio. Al cabo, podría considerarse que la prescripción tassiana de que la épica debe fundarse en historia de religión 
busca en la épica, por lo tanto, los mismos valores que en la historia detectaban los intelectuales del xv, básicamente el de magistra vitae, que resultan del todo opuestos a la ficción caballeresca. ${ }^{17}$

La atracción del estamento nobiliario y monárquico por el género historiográfico es uno de los fenómenos que mejor definen la producción intelectual del siglo Xv castellano. ${ }^{18}$ Nunca antes, como afirma Robert B. Tate, se habían compuesto tantas y tan diversas formas de crónicas en Castilla (entre las que cabe incluir textos afines como las semblanzas biográficas y las genealogías, la gran mayoría dedicadas a personajes de la nobleza) ${ }^{19}$ a lo que debe sumarse una rica producción de traducciones, en su mayor parte de textos históricos, que poco tienen de interés humanista y mucho de deleite medieval en las gestas antiguas, en especial desde la irrupción en la Península de Tito Livio, en lo que constituye una curiosidad y una novedad para monarcas y nobles poco o nada versados en el latín y deseosos de tener a su alcance estas viejas historias en traslaciones antes adaptadas a los modos de lectura medievales que interesadas por las finas reconstrucciones humanistas..$^{20}$ La razón se debe también a una conciencia de clase que sólo paulatinamente abandonará el menosprecio del cultivo de las letras y sólo cuando esa misma nobleza advierta las posibilidades pragmáticas del dominio de la pluma. ${ }^{21}$ Un poder que, andando el tiempo e instigado por los

verdadera no es sino un desarrollo de la épica de tema histórico para acercar al género a presuposiciones más próximas a los criterios humanistas, al amparo de la poética neoaristotélica.

17. Vid. Tate (1994).

18. Vid. Rico (1983).

19. Tate (1970).

20. Vid. Rico (1983: 266): «El mercado había hecho accesibles muchos textos de clásicos y clasicistas; con ellos se dejaba alimentar la vieja curiosidad de los poderosos por la historia y la novela histórica. Que la aristocracia disfrutara con selectos juguetes recién comprados, que los héroes paganos se pusieran de moda, no era cosa demasiado alarmante: un espíritu equilibrado podía incluso sacarle partido moral, político y 'de cavalaria'".

21. La cuestión es, a mi juicio, muy relevante ya que explica también la divergencias entre el modelo de cortesanía italiano y el modelo caballeresco y militar de la España del Quinientos, que ilumina la idea (diversa) que de la épica tienen unos y otros. Russell (1978), tras Round (1962), estudia de qué forma la hostilidad hacia las letras por parte del estamento caballeresco en la Castilla del Xv es una de las razones que expli- can también la distinta consideración de la recuperación de los textos clásicos en la tradición hispánica que obliga, por lo tanto, a plantearse un "humanismo" de muy diverso cuño o que, a fin de cuentas, pueda hablarse de tradiciones culturales distintas. Sobre esta cuestión Lawrance $(1985,1986$ y 1990) ofrece una revisión y corrección de lo esbozado por los dos autores anteriores. Véanse también Morrás (1993) y Pontón (2001). Esta reticencia al cultivo de las armas $y$ las letras sólo se verá superado, justamente, por la conciencia cada vez más plena de que la fama depende de la palabra escrita, como atestiguan numerosas fuentes contemporáneas. Véase Lida (1952). El caso es que el consabido topos de las armas y las letras plantea la oposición del humanismo latinista italiano frente a una cultura castellana más interesada en «revitalizar la parte de la cultura medieval que descendía de la tradición clásica» (Russell, 1978: 229). Según este mismo autor, España no se abriría plenamente al humanismo hasta mediados del XvI, especialmente gracias a la traducción de $\mathrm{Il}$ Cortigiano auspiciada por Garcilaso, quien, soldado y poeta, ejemplarizaba la teoría de la cortesanía expuesta por Castiglione. Pese a ello, sin embar- 
Reyes Católicos, redundará en beneficio de la imagen de los mismos soberanos, que auspiciarán ya no sólo traducciones, como ocurría especialmente en el reinado de Juan I, sino que protegerán efectivamente a humanistas e intelectuales e impulsarán la redacción de historiografías oficiales. El interés por la Clasicidad permite, pues, captar el desplazamiento paulatino de poder de las manos de nobles y aristócratas a una monarquía centralizada: si bien los primeros fueron los que principiaron esta recepción inicial de los autores clásicos y de algunos humanistas (frente a la oposición de teólogos y escolásticos, que veían asaltado y saqueado su feudo por los que consideraban unos legos en la materia, que sólo veían en las letras un modo de resarcirse políticamente), a medida que avanza el siglo (y a medida que los studia humanitatis se imponen en Castilla, especialmente gracias a la labor de Nebrija y los intelectuales de su generación), ${ }^{22}$ el cultivo de las letras se especializa, se personaliza y se latiniza de forma creciente, si bien éstas se ven sometidas, en gran medida, a la mediación del mecenazgo regio y nobiliario.

Como ha estudiado Julian Weiss, ${ }^{23}$ el reinado de Juan II (1406-1454) fue testigo de la consolidación de una nueva clase de aristocracia que hizo de la empresa intelectual y poética su razón de ser, que importaría los métodos escolares para realzar la literatura vernácula (ya fuera «original»o en traslaciones al romance de obras clásicas o humanistas) guiada por la idea de que ésta debía

go, la realidad contemporánea de una España que es cabeza del mayor imperio conocido hasta el momento hace, a mi entender, que persista la impronta militar tan arraigada en la cultura española. Los prólogos programáticos de la épica española recuperan la idea cuatrocentista de que las letras prestan, ante todo, un servicio a los logros acometidos con las armas. Y, de hecho, la obra y figura de Garcilaso sería entendida en términos igualmente de oposición al modelo cortesano italiano: Francisco de Medina afirma, en la epístola a los lectores de las Anotaciones de Fernando de Herrera, que el enriquecimiento de la propia lengua es consecuencia de los progresos militares ( ccada cual nacion tanto mas adornava su lenguaje cuanto con mas valerosos hechos acrecentava la reputacion de sus armas» de forma que «veremos estenderse la magestad del lenguaje Español, adornada de nueva i admirable pompa, hasta las ultimas provincias, donde vitoriosamente penetraron las vanderas de nuestros exercitos», cito por Obras de Garcilasso de la Vega con anotaciones de Fernando de Herrera, Sevilla, Alonso de la Barrera, 1580, fols. 1, 12), una opinión secundada por el propio comenta- rista y poeta hispalense cuando sostiene que el pobre estado en que se encuentra la lengua no se debe a la falta de ingenios sino al hecho de que "atendiendo a cosas mayores los que le pudieron dar gloria y reputación, o no inclinándose a la policia y elegancia de estos estudios, la desampararon de todo punto en esta parte». Así, aduce Herrera que la lengua de una nación forjada por el uso de las armas como España posee las virtudes viriles y magníficas de la milicia y por ello es "grave, religiosa, honesta, alta, magnífica, suave, tierna, afectuosísima y llena de sentimientos, y tan copiosa y abundante, que ninguna otra puede gloriarse de esta riqueza y fertilidad más justamente», mientras que la toscana es «libre, lasciva, desmayada y demasiado enternecida", lo que le lleva a concluir que «la española se debe tratar con más honra y reverencia, y la toscana con más regalo y llaneza» (Cito por la edición de Gallego Morell, 1972: 307, 313).

22. Vid. Rico (1978). Sobre la politización de la literatura cuatrocentista véase Deyermond (1988).

23. Vid. Weiss (1990), quien tampoco acepta la idea de un "prerrenacimiento» 
contribuir a la educación del noble y del gobernante. Así pues, el «humanismo vernáculo» del $\mathrm{xv}$, frente al humanismo latinista italiano, atendería antes a la utilidad de la literatura para el regimiento de la cosa pública y, en un contexto de desconocimiento general del latín por parte de los estamentos más elevados de la sociedad, privilegiaría la producción en vulgar, en un deseo creciente de aspirar a la conciliación de las armas y las letras. La idea de que las letras habían de servir a la actuación política situaban al letrado no profesional en un papel de mediador privilegiado, y este papel sería explotado en algunos casos para cumplir con unas estrategias, como en el caso de Enrique de Villena, mucho más personales. La traducción de la Eneida realizada por el de Aragón resulta fundamental para el tema de estas páginas. Pese a tener una influencia posterior restringida, la obra de Villena resulta de sumo interés para el tema de estas páginas porque no sólo ilustra los modos particulares de la recepción de los textos clásicos en la Castilla del Xv sino, ante todo, porque nos permite pulsar una visión de la obra del mantuano que determinaría el «virgilianismo político» de la épica española del Quinientos y su predilección manifiesta por la narración histórica. En otro orden de cosas, nada alejadas de esta idea principal, interesa también reflexionar sobre la lectura alegórica villenesca de la Eneida, que puede seguirse parcialmente en un autor fundamental para la tradición épica hispana como Juan de Mena. En este sentido, la consideración de ambos autores cuatrocentistas, en su contexto cultural, proporciona unas pautas de lectura del corpus épico del siglo siguiente específicamente hispanas, con un claro sentido político, que contribuye a perfilar las evidentes diferencias con la tradición humanista italiana.

\section{Traducción y glosas de la Eneida. Enrique de Villena y la configuración del «virgilianismo político» hispano}

La traducción de Enrique de Villena tiene mucho de personal en su visión de la obra virgiliana y en su propia consideración de la tarea del intelectual (él mismo, en este caso) como el mejor propagandista de las gestas regias en un contexto histórico donde se escuchaban voces a favor y en contra de las veleidades intelectuales de la nobleza. ${ }^{24}$ Como ya ha señalado la crítica, don Enrique aborda una traslación más próxima a presuposiciones medievales, en

24. Y que teñiría la semblanza escrita por Hernán Pérez de Guzmán en sus Generaciones y semblanzas (ca. 1450) en la que, si bien destacaba la sutileza y el ingenio poético del biografiado, no escatimaba una crítica a su falta de interés por las cosas mundanas y propias de un noble: «era este don Enrrique ageno y re- moto, no solamente a la cavallería, mas aun a los negoçios del mundo e al rigimiento de su casa e fazienda, era tanto inábile e inabto, que era grant maravilla» (Fernán Pérez de Guzmán, Generaciones y semblanzas, cito por la edición de José Antonio Barrio, Madrid, Cátedra, p. 151). Véase Folger (2003). 
el sentido de que lo que importa verdaderamente, pese a la célebre afirmación de que la suya es una traducción «de palabra a palabra», es llegar a desentrañar el meollo de la «doctrina latente», ${ }^{25}$ que es, en suma, la que debe servir para el buen funcionamiento de la república. Asimismo, en un momento en el que moralistas y teólogos se mostraban contrarios a la consideración alegórica de la poesía, como clamaban Alonso de Cartagena o Vicente Ferrer, la concebida por Villena para la correcta interpretación de Virgilio pasa por el necesario sometimiento de la relación cronística a las técnicas retóricas y poéticas: la alegoría descubierta en las Glosas es, en suma el «modo de expresión específico de la poesía». ${ }^{26}$ Esta necesidad del velamen confiere carácter filosófico y moral a la poesía y, al mismo tiempo, es requisito indispensable para la perdurabilidad de la obra. La Eneida deviene, pues, una «narración histórica elocuente», exponente de los valores de la historia y de la grandeza del estilo retórico que, a fin de cuentas, es, según el criterio villenesco, el que mejor ayuda a distinguir a la buena de la mala historiografía. ${ }^{27}$

Villena expone todas estas cuestiones en los textos prologales a su traducción, esto es, en la Carta a Juan II de Navarra, dedicatario y peticionario de la obra, y en el «Prohemio». Ya en el primero de estos textos se perciben las aspiraciones personales del traductor de convertirse en el escritor que dé a conocer las gestas del monarca: si, a petición de Juan II de Navarra, se ha decidido, pese a la humildad de la «romançial texedura», ${ }^{28}$ a vulgarizar la Eneida de Virgilio, destaca también su deseo de ser «ocupado» en demás tareas «en vuestra gloria e onra redundantes». ${ }^{29}$ Pese a sostener que puedan ser éstas distintas de la «sçientífica e ystorial scriptura» no hay que dejarse engañar.

25. Cito por la edición de Cátedra (1989ª: 32). Véase Russell (1985: 45-50).

26. Miguel Prendes (1998: 9). Sobre la cuestión alegórica en Villena, ver también Weiss (1990: cap. 3).

27. Cátedra (1989 $: 43)$.

28. Cátedra (1989: 3). La frase es muy indicativa de la sentida oposición entre los «romançistas» y los «letrados» (latinistas) del período cuatrocentista, a la postre un indicio del sentimiento de superioridad de la minoría letrada de la época de Juan II y Enrique IV, de la que Villena se erige como representante y mediador (véase, por ejemplo, la respuesta que Alonso de Cartagena da al elogio de las letras romances del Marqués de Santillana: «fablemos romance perfecto, y do será menester fablemos latino; qui lo entiende lo entienda; el otro quede por necio», apud Round, 1962: 210). Villena incidirá en esta distinción en re- petidas ocasiones, especialmente en las Glosas (que, al igual que el Prohemio, fueron añadidas a instancias de Íningo López de Mendoza), según explicita en la segunda a su epístola, en la que incide en la importancia y pertinencia de sus propios comentarios para comprender el sentido histórico y el moral de la Eneida: «A todos los quel presente libron querrán e farán trasladar plega de lo escrevir con glosas, segund aquí está complidamente, porque los secretos ystoriales e los integumentos poéthicos lleguen a noticia de los leedores; e non presuman nin atienden el texto solo trasladar, que por su obscuridad pariríe, siquier presentaríe, muchas dubdas e non sería tan plazible al entendimiento de los leedores, mayormente romançistas» (Cátedra (1989: 6). Véase también, en este mismo sentido, la glosa 109 al «Prohemio», apud Cátedra (1989a: 66).

29. Cátedra (1989a: 4). 
Si ahora que no cuenta con el favor completo del monarca ha cumplido tan gustosamente con el encargo, qué no hará si el trato hacia su persona cambia: «esa hora cantará mi lengua grandes loores e fará resonar vuestro nombre; e quanto Caliope graçiosamente otorgarme quiso / enfundiré en la recordaçión de vuestra gloriosa fama.» ${ }^{30} \mathrm{La}$ intención de la epístola al rey de Navarra es ya muy clara: demostrar su valía no tanto como traductor sino como autor de una obra venidera, la que escribirá en beneficio de la fama y la memoria de Juan II, para la que evidentemente posee el ingenio y la formación necesarias. La traducción comentada de la Eneida servirá, a fin de cuentas, para que el rey vea, ante todo, el buen servicio que las letras puede prestarle, y, para demostrárselo, nada mejor que una obra, como explicita en la glosa segunda, ${ }^{31}$ con un sentido histórico y moral que sirve al "crescimiento e fructo de moral doctrina, a reparación de la vida çevil, que tancto en la sazón presente deformada paresçe.»" Sólo queda, pues, para que el rey y los leedores, «mayormente a los quel mar de las ystorias non han navegado», comprendan el verdadero significado de la obra de Virgilio, que él se lo explique debidamente en el prohemio que precede a la traducción.

El «Prohemio», en realidad, no hace sino amplificar y justificar la doble intención de esta traducción de la Eneida, es decir, la del propio Virgilio, puesta en boca del traductor e identificada con el «velo poéthico», y la del propio Villena, que se sirve del texto del poeta latino como punto de partida y repositorio de una segunda intención más personal y no tan velada: convertirse en un nuevo Virgilio y ser el cantor que celebre la memoria del monarca. ${ }^{33}$ La Eneida virgiliana, en suma, ha dado paso no a una traducción stricto sensu sino a otra obra, la «Eneida» de Villena, que no tiene nada que ver con el Virgilio de los humanistas. De fondo, las pretensiones de este noble ducho en las letras y ciencias se enmarcan en un discurso más amplio sobre los beneficios (políticos) de la historia y la poesía, al tiempo que toma y adapta las herramientas de los profesionales de las letras para la mejor comprensión de soberanos y nobles, al cabo, legos y «romançistas», que gustan de leer determinados géneros que confirman y confieren al estamento de la caballería una pátina de clasicidad.

La adopción de las herramientas de los filósofos escolásticos se explicita en el accessus con que se abre el «Prohemio», a través de una Vida de Virgilio en la que se detectan datos difundidos por Servio y Donato. ${ }^{34}$ En la extensa sem-

30. Cátedra (1989a: 5).

31. Vid. supra, n. 28.

32. Cátedra (1989'a : 5)

33. Como afirma Weiss (1990: 18): «...on every possible occasion, Villena tries to cast himself in the same role as Virgil, suggesting also that the classical poet wrote with him in mind (...) In this way, a theoretical statement is incorporated into the larger strategy of the text, which is to proclaim Villena's intellectual talents and potential usefulness as a political propagandist.»

34. Vid. Cátedra (1989: 16, n. 20). La «Vida» referida por Villena cuenta con edición inde- 
blanza del mantuano, interesa aquí referir la anécdota del encargo de Augusto quien, complacido por la elocuencia y reputación del poeta «reposó la confiança imperial en él, vista la suficiençia virgiliana, discreçión e modestia, que non dubdó encomendarle la ordenança de su ystoria e fazimiento de su corónica, —que sinon a los más scientes encomendar non era entonces costumbre la resçitaçión en scripto de las gestas ymperiales-, queriendo, por lo encargar a tan glorioso e claro varón, canonizar sus estrenuos fechos e perpetuar su indelible memoria, dexándolos scriptos en el sçientífico e dulçe stillo virgiliano.» ${ }^{35} \mathrm{El}$ pasaje es, a $\mathrm{mi}$ juicio, muy indicativo de lo que el mismo Villena ya expresaba en la carta al rey de Navarra: la Eneida es, ante todo, una historia, una crónica, cuya finalidad es "canonizar» las gestas imperiales y conservar su memoria mediante un estilo, dice el traductor-comentarista, dulce y científico. Es la manipulación suma de una idea de la historia y de una incipiente teoría literaria (no consignada, por cierto, en un tratado de poesía) conforme a la cual se hace del poema épico una forma de historiografía embellecida mediante la retórica para la conservación de la memoria de las grandes hazañas. Para que no quede duda del valor que esta forma de escritura puede tener para el poder político, dice a continuación: «i $\mathrm{O}$, quánta bienaventurança esa alcançaron sazón los muy nobles fechos del çésar Octhoviano por tan eloqüente lengua resçitados, syn quien non durara tan divulgada su estendida e comendable famals. ${ }^{36} \mathrm{Si}$ el monarca quiere, en definitiva, que quede memoria de sus «estrenuos fechos» sólo podrá conseguirlo, como Augusto, contando con un Virgilio, un "claro varón» capaz de domeñar el lenguaje como pocos. El pago de este servicio consiste, como era de esperar, en la protección de las letras, si bien no a cualquier precio: sólo los más dignos, es decir, los más letrados, deberían ser los encargados de la escritura histórico-poética de las gestas monárquicas. Esta condición, apuntada de forma oblicua en el texto del Prohemio, se revela en toda su importancia en las glosas que comentan este pasaje y otros anteriores, que no están exentos de una crítica velada a la situación de inopia intelectual en la que viven muchos nobles: así, hablando de Augusto, refiere en una de las glosas que «non despresçiavan la sçiençia en ese tiempo, antes avían por bien que los grandes señores fuesen sçientes e letrados, e mayormente el emperador, que es señor universal soberano». ${ }^{37} \mathrm{El}$ emperador, pues, pudo contar con una crónica que celebrara su fama gracias a que él era, también, conocedor de las «sçiençias» y poseía los conocimientos necesarios para elegir al mejor candidato posible, esto es, Virgilio. A cambio, dice Villena también en

pendiente, de Delgado (1979), y ha sido estudiada más recientemente por Macías Rosendo (2006), quien sostiene que Villena guió su redacción y adaptación del material al uso sobre la vida virgiliana de un «espíritu de manual» (p. 7) a partir de una recopilación de materia- les antes que de una lectura directa de Servio y Donato.

35. Cátedra (1989: 23). Las cursivas son mías.

36. Cátedra (1989a: 23). Las cursivas son mías. 37. Cátedra (1989ª 44, gl. 35). Las cursivas son mías. 
una glosa, le corresponde proteger a quien tanto puede hacer en beneficio de su fama póstuma. ${ }^{38}$ Es evidente que el de Aragón ha retomado y manipulado en beneficio propio el antiguo tópico de las letras al servicio de la fama recogido en un célebre pasaje del Pro Archia ciceroniano, de gran difusión en las letras castellanas cuatrocentistas (y que retomarán loa autores épicos del Quinientos). ${ }^{39}$

La defensa del papel de las letras en la conservación de la fama de los grandes señores, por medio de la narración histórica, se convierte en el argumento principal para postular la reciprocidad que debe establecerse entre el escritor y el objeto de su escritura. Esta ayuda recíproca, expresada mayormente en las glosas, permite ver cómo Villena va más allá del topos para arrimar el agua a su molino. Prácticamente, el grueso del texto que sigue del «Prohemio» insiste en mostrar, por medio de la explicación moral del velo virgiliano, la extraordinaria capacidad intelectual del que escribe, muy superior, viene a decir, a los cronistas contemporáneos, en una demostración de orgullo poco habitual y que constituye, a la vez, la explicación de su idea de la alegoría virgiliana. No basta, a fin de cuentas, conocer los datos que deben consignarse en la crónica del rey: la responsabilidad del cronista está en saber contar «coloradamente» dichas gestas para que la loa no resulte demasiado simple y evidente ni sea puesta en duda. Con ello, Villena establece una distinción evidente entre los poetas (los «sçientes», los «letrados») y los que denomina «escrivanos de cámara», los «romançistas», unos simples aficionados que, no obstante, son los que ahora escriben (mal) las crónicas de los monarcas. ${ }^{40} \mathrm{Y}$ las escriben mal porque se dedican simplemente a transcribir los hechos tal como fueron sin disponerlos de acuerdo con lo que dictan la retórica y la poética, es decir, sin tener presente que lo que importa verdaderamente de la historia es el engrandecimiento del sujeto. ${ }^{41}$

La restitución de una situación tan deseable como la que conocieron el Augusto y el Virgilio de la Antigüedad en una Castilla falta de verdaderos «coronistas» guía la personal e interesada estrategia villenesca que, a la postre, resulta ser todo un ejercicio de autopropaganda tan embellecido como deben serlo las crónicas que propone, o, más probablemente, la crónica que él mismo se ofrece a escribir sobre las gestas del padre del monarca, Fernando de Antequera:

Casi que diga que desto se duele más, de non ser recordada como cumplía la memoria del rey su padre del dicho rey de Navarra, que fue el rey don Fernando de

38. "Aquí demuestra que los emperadores antiguos, ansí como éste fizo, non solamente loavan los sabidores, mas fazíenles merçed sosteniéndolos onradamente (...) En esto mostró gran discreçión el emperador, dando sus dones a tan sçiente persona que con su lengua e dezires le podría fazer tancto serviçio.» (Cátedra, 1989a: 47, gl. 42).
39. Vid. Vega (2010: 129-135).

40. Esta oposición despunta aquí y allá en muchas de las glosas subsiguientes. Véase, por ejemplo, la glosa 68, apud Cátedra (1989a: 54). Notando quizá que su censura podría resultar excesiva la disfraza de «buen zelo»: véase la glosa 76, apud Cátedra, 1989a: 56.

41. Cátedra (1989 : 43-44). 
Aragón, segúnd ya es dicho en una glosa de suso sobre la palabra parental. Dolíese dello por dos cosas: porque fizo notables e aseńalados fechos en poco tiempo e porque ovo con él grand logar. E queriendo en conosçimiento desto acarrear su serviçio, siquiere loor, suscita con este dezir la voluntad del rey, su fijo, dicho para fazer bien ordenar su corónica. ${ }^{42}$

Ésta y no otra es la verdadera «yntinçión» de la «Eneida» de Villena, la de convertirse en cronista del soberano para así gozar de su favor. El texto del «Prohemio», como veremos en el apartado siguiente, no deja de ser una construcción al servicio no tanto del monarca cuanto del escritor, que se sostiene en una idea cultural de fondo, la salvaguarda de la memoria gracias a las letras, de plena actualidad en los debates intelectuales de la Castilla del xv. Esta segunda y más pragmática intención autorial de la obra de Villena recubre y se adueña de la que supuestamente tuvo Virgilio, al tiempo que erige una idea de la alegoría épica y de la escritura poética de importancia fundamental para la tradición épica posterior. Porque librada de las necesidades más inmediatas del autor y trasladada más generalmente a la idea de la épica como escritura histórica destinada a la conservación de las grandes gestas, la teoría literaria expresada por Villena resultará plenamente trasladable y aplicable a la escritura épica quinientista.

\section{"Toda su ystoria es llena de fructuosa doctrina»: épica, historia y regimiento de príncipes}

Buena parte del «Prohemio» de Villena a la traslación de la Eneida se ocupa de aclarar la que él dice que es la intención del poeta. Dicha intención resulta ser, en un primer estadio, la escritura histórica al servicio de la recordación de las gestas de Octaviano; pero ésta constituye sólo la lectura primera y más literal, que debe ser necesariamente trascendida para acceder al meollo principal de la obra que es, ante todo, moral. ${ }^{43}$ Esta segunda lectura más profunda resulta sólo accesible a los doctos y, en calidad de tal, Villena se dispone a explicitar al «symple leedor» ese sentido más profundo, oculto tras el velo virgiliano. Lo que sigue es, fundamentalmente, una exposición de dicho sentido y la construcción de una teoría de la alegoría poética que debe demostrar la sobrada competencia del traductor en los saberes científicos y morales. Si el sentido literal cumple, pues, un claro servicio práctico (político) a los poderosos, en tanto que se postula que

42. Cátedra (1989a: 56, gl. 77).

43. "Quiere dezir que non solamente fue su intinçión de Virgilio que por estos dezires Octhoviano fuese loado e recordado en fama gloriosa, mas aun, e más principalmente, por reprehender los viçios e favorizar las virtudes, porque buenas costumbres en el mundo por esta obra sembradas fuesen. E esto fue primera intinçión e alabar a Octhoviano por segunda intinçión.» (Cátedra, 1989ª 50, gl. 51). 
la Eneida es ante todo un tipo de discurso histórico destinado a la conservación de la fama, la parte más teórica, la alegoría, no deja de estar libre de una intención más pragmática, si bien de índole más personal y disimulada. El propósito general al que sirve esta lectura alegórica continuada del poema virgiliano, en suma, trasciende la visión de la poesía como propaganda regia si bien, no exenta de un cañamazo ideológico, la dirige al elogio de las buenas costumbres. El valor moral que cabe extraer de la lectura profunda de la Eneida revierte nuevamente en la vida política con el ropaje de un espejo de príncipes.

La cuestión de alegoría villenesca enlaza sin fisuras con su idea de que la historiografía debe guiarse por el modelo de la Eneida. Esto implica, como apunta Cátedra, ${ }^{44}$ que la verdad de los hechos debe someterse a las técnicas retóricas lo que, al cabo, autoriza lo que viene a llamar «fermosas simulaçiones», que sirven al engrandendicimiento de Octaviano. Estas simulaciones o fingimientos son la clave de su concepto de la relación histórica como género dependiente de las técnicas poéticas. La verdad cae en un segundo plano porque lo que importa realmente es ensalzar al sujeto: "De manera que piensa el symple leedor que Virgilio quiere contar en esta obra los fechos de Eneas, e aquél ministra loores de Octhoviano: so el velo poéthico e colores retoricales discretamente e palliada fiere aquel señal a do non paresçía tyrar.» ${ }^{45}$ Estamos ante un planteamiento de la historiografía ciertamente polémico, que hallaría respuesta, por ejemplo, en el prólogo de Fernán Pérez de Guzmán a las Generaciones y semblanzas, que rompería una lanza, en efecto, por la preponderancia de la verdad en la relación historiográfica, si bien no renunciaría a la «buena retórica para poner la estoria en fermoso e alto estilo». ${ }^{46}$ Lo que me interesa aquí es cómo dichos fingimientos

44. Vid. Cátedra (1989 : 43-44).

45. Cátedra (1989a: 24). Las cursivas son mías. Éste es el argumento que sostiene la crítica villenesca a los «escrivanos de cámara»y, por lo tanto, a las crónicas que se escriben en su época. Como apuntará en una de las glosas a un pasaje posterior, la relación histórica debe someterse al ordo artificialis retórico, porque este recurso es, propiamente, el que embellece las obras y las convierte en buenas historias: «E pónenlo [los escribanos de cámara] por tal contynuaçión como si ordenasen proçesos, non curando del orden artyfiçial que guarnesce mucho las obras, donde se siguen todos los inconvenientes que en el texto adelante dize e muchas más que al presente non cumple detigyr.» (Cátedra, 1989ª 55), gl. 69).

46. "Muchas veces acaesçe que las corónicas e estorias que fablan de los poderosos reyes e notables prínçipes en grandes çibdades son avidas por sospechosas e inçiertas e les es dada poca fe e abtoridat, lo qual, entre otras cabsas, acaeçe e vien por dos: La primera, porque algunos que se entremeten de escrivir e notar las antigüedades son onbres de poca vergüeńa e más les plaze relatar cosas estrañas e maravillosas que verdaderas e çiertas, creyendo que no será avida por notable la estoria que non contare cosas muy grandes e graves de crer, ansí que sean más dignas de maravilla que de fe. (...) El segundo defeto de las estorias es porque lo que las corónicas escriven es por mandado de los reyes e prínçipes. Por los conplazer e lisonjar, o por temor de los enojar escriven más lo que les mandan o lo que creen que les agradará, que la verdat del fecho como pasó. E a mi ver para las estorias se fazer bien e derechamente son neçesarias tres cosas: la primera, que el estoriador sea discreto e sabio, e aya buena retórica para poner la estoria en fermoso e alto estilo; 
pasan por el tamiz del velo poético y se justifican por él: «En esta obra Virgilio introduze virtuosas costumbres, inclinando a los oyentes a fien fazer. ${ }^{47}$

Las simulaciones, pues, no sólo están autorizadas por el sometimiento de la narración historiográfica a los dictados de la retórica sino que son absolutamente necesarias para comprender que la Eneida es, como dirá más adelante, un «espejo doctivo». ${ }^{48}$ En este punto, Villena abandona la senda de los comentarios antiguos (que recomendaban la mezcla de verdad y ficción como elementos propios de la épica $)^{49}$ y sigue los parámetros medievales dictados, entre otros, por Fulgencio y su versión alegórica de la Eneida. ${ }^{50}$

porque la buena forma onrra e guarneçe la materia...» (Cito por la edición de José Antonio Barrio, Madrid, Cátedra, pp. 59-60, 62-63) Sobre esta polémica entorno a la historiografía vid. Carr (1986). Como ha establecido Cátedra (1983: 188, n. 5), el rechazo de Pérez de Guzmán, que debe complementarse con la poco favorecedora semblanza que hace del mismo Villena, es más bien tópico y responde antes a intereses políticos de los miembros de la cancillería, contrarios al «intrusismo» de los nuevos dictatores.

47. Cátedra (1989: 24).

48. Cátedra (1989a: 26). En la dedicatoria de la versión catalana de los Dotze treballs d'Hèrcules también califica a la obra de «espill» de la «cavalleria moral» destinado a la imitación de las virtudes i, por extensión, al mantenimiento del «bé comú»: «faça fruit per imitació exemplar i creixement de virtuts i obstacle de vicis i serà espill actual als gloriosos cavallers en armada milícia, movent lo coratge de aquells en no dubtar los aspres fets de les armes i emprendre grans i honrosos partits endreçant-se sostenir lo bé comú, per qui milícia fon atrobada." (Cito por la edición de Riquer, 1990: 277. Las cursivas son mías).

49. En su definición del poema épico, Servio aduce que corresponde a éste el estilo grandilocuente, la interacción de dioses y hombres y la mezcla de la verdad y la ficción: «est autem heroicum [carmen] quod constat ex divinis humanisque personis continens vera cum fictis (...) Est stilis grandiloquus qui constat alto sermone magnisque sententiis» (Cito por la edición de Thilo y Hagen, 1961, 4, ad Aen. Praef.) Dicha definición compendia y adapta, de hecho, la antigua oposición retórica relativa al ordo naturalis y al ordo artificialis, amén de otros materiales precedentes sobre poética, en una presentación del epos como forma específica de escritura histórica, cuya poeticidad depende del respeto de unas normas que el escoliasta virgiliano aduce en diversos comentarios. Estos requisitos pueden resumirse en dos principios fundamentales: que lo fingido no debe alejarse en exceso de la verdad (cf. Servius ad Aen. III, 46, apud Thilo y Hagen, 1961, 344) y que el poeta no debe aducir servilmente la historia (cf. Servius ad Aen. I, 382, apud Thilo y Hagen, 1961, 129). Por cierto que este último condicionante es el que sirve al comentarista para negar que la Farsalia de Lucano deba ser considerada poesía. Para un tratamiento más detallado de esta cuestión y su pervivencia en textos humanistas, véase Vilà $\left(2010^{\mathrm{b}}\right.$ : en prensa).

50. Hasta la fecha, desconocemos qué manuscrito habría utilizado Villena para la traducción y qué materiales paratextuales tenía a su alcance. Como sostiene Valero (2005: 122), lo más probable es que el de Aragón se sirviera de un códice con el comentario de Servio interpolado con otras referencias, entre las que se habría difundido el De Virgilianae continentia de Fulgencio, al que Villena lee, por lo tanto, de forma indirecta. Esto explica la confusión del traductor cuando aduce, en su explicación de la alegoría virgiliana, que se debe a Servio la glosa que certifica "los grandes misterios en esta Eneyda contenidos» (Cátedra (1989): 26). Véase también la glosa 341 al Libro I, apud Cátedra (1989a: 264), cuando en realidad está trasladando el contenido principal del comentario alegórico de Fulgencio, posteriormente desarrollado por Bernardo Silvestre. Tal confusión podría explicarse también por el hecho de que, en determinados pasajes, Servio recurre a la explicación alegórica, en concreto 
De la mano de Fulgencio, Villena reconduce la historicidad de la Eneida a temas más elevados, es decir, «reconstruye» la supuesta intención virgiliana de que la Eneida sea un «espejo doctivo» cuyo fin es aleccionar al «leedor» para que viva virtuosamente: «E por esta manera toda su ystoria es llena de fructuosa doctrina e, si el leedor supiere prescrutar el poethal intento, en tal manera que qualquier de los estados del mundo e cada una de las hedades e qual pluguiere de las religiones puede tomar doctrina e libre para bevir virtuosamente. ${ }^{51}$ El velo alegórico es, para Villena, una característica definitoria de la poesía («Velo se llama a la cubierta ho palliaçión con que los poethas suelen fablar» $)^{52} \mathrm{y}$, al cabo, es la que sirve para confeccionar buenas historias, es decir, aquellas que no contienen "manifiestas adulaçiones», causadas por la falta de aptitudes literarias necesarias para ocultar los prejuicios de los escritores. Lo que se necesita, en resumidas cuentas, son historias embellecidas, en las que el halago del poderoso y de la vida virtuosa que éste supuestamente representa (en el caso de la Eneida, a través de Eneas como alter ego de Augusto) no sea evidente, sino «escuro e velado» para los profanos.

La alegoría villenesca tiene, pues, una evidente base histórica que es la que determina que ésta tenga unos destinatarios prioritarios, los caballeros, de forma que deviene una «ylluminaçión de la cavalleril doctrina e conservaçión de la políthyca vida». ${ }^{53}$ Es decir, que la alegoría suma un interés ético a otro civil. ${ }^{54}$ Esta conjunción de intereses no sería un signo del "prehumanismo» villenesco (en el sentido de que deba considerárselo introductor de las nuevas doctrinas italianas), porque no debe olvidarse que su obra es profundamente medieval y que en realidad fagocita las novedades de los modernos autores (posiblemente de forma más visible en los Doze trabajos de Hércules) y las filtra en función de sus necesidades particulares. No obstante, esta lectura es significativa de un modo de proceder sumamente pragmático frente a, como ha estudiado Cátedra, un uso de un Petrarca absolutamente despersonalizado. ${ }^{55}$ En este sentido, de compararse la percepción de la alegoría en ambos autores, se percibe a las claras que ésta

a propósito de las Bucólicas, que motivaría la adaptación de este tipo de lectura a la Eneida, a partir especialmente del comentario inicial dedicado al libro VI donde explicita que éste está repleto de ciencia, y gracias a la identificación de idénticos fines entre épica y poesía bucólica como alabanza del poder político e imitación de modelos precedentes. La diferencia esencial estriba en que la tradición medieval dotará a esta argumentación, apoyándose asimismo en los comentarios retóricos de T. C Donato (leído, por ejemplo, por Cristóforo Landino), de una visión de conjunto auspiciando lecturas alegóricas continuadas y no sólo referidas a pasajes particulares, como se establecía en los comentarios clásicos. Al respecto, véase Vilà $\left(2010^{\mathrm{a}}\right.$ y $\left.2010^{\mathrm{b}}\right)$.

51. Cátedra (1989a: 25). Las cursivas son mías.

52 Cátedra (1989a: 49, gl. 50).

53. Cátedra (1989a: 31).

54. Según Cátedra (1983: 202), en línea parecida a lo expuesto por Coluccio Salutati en el Tratado de seculo et religione, que el estudioso considera la obra más medieval del canciller florentino.

55. Sobre la presencia de algunos humanistas en la obra de Villena, vid. Cátedra (1983). 
posee un cariz muy distinto que marca una andadura y una adaptación diversa. ${ }^{56}$ En suma, Villena tiene un claro destinatario para su «espejo doctivo», la nobleza castellana, a la que la Eneida por él traducida y glosada debe preparar y formar en las virtudes encarnadas en los clásicos para el mejor desempeño de sus funciones políticas, o, en palabras del de Aragón, en «la bienaventurança del ymperio, que es en los estados la postrimera feliçidat que los omnes alcançar pueden..1 ${ }^{57}$ Finalmente, la «Eneida» de Villena, con Miguel Prendes, refleja «los valores de la clase dominante, desempeña el mismo papel ideológico al servicio del imperio que había realizado ya en los tiempos de Donato, Servio y Macrobio, pero adaptada ahora a las circunstancias específicas del temprano Cuatrocientos..158

Lo que me parece más significativo para entender el marco cultural en el que se desarrollará la idea de la épica en el Quinientos español es que, en la concepción de Villena, la Eneida es, ante todo, Historia, obra de un poeta-filósofo que pone su talento al servicio del estado. Augusto deviene así un emperador protector de las letras y de quienes las cultivan, en una interdependencia ideal entre poder y escritura (que Villena, al cabo, ansiaba para sí) que reclama la existencia de historiadores con aptitudes literarias. La Eneida (y, por extensión, la poesía histórica) resulta ser para Villena, como lo será para los poetas épicos del Quinientos, una herramienta dirigida al regimiento de la cosa pública, al halago del soberano y a la conservación de la fama póstuma de sus acciones, pero también, en una obra que traduce y glosa "los angélicos conçebimientos virgilianos», creación personal de un autor que aspira a ser, como los poetas épicos del siglo siguiente, un «nuevo Virgilio» que busca en la escritura épica e histórica (que Villena identifica claramente mediante una traducción en prosa) cumplir con sus ambiciones personales. ${ }^{59}$ El núcleo narrativo de la obra, la "historia», es el primer peldaño

56. Según Petrarca, Virgilio pretendía encarnar en Eneas al hombre perfecto, una perfección que consiste ante todo en la virtud: «cuius finis ac subiectum, ut ego arbitror, Vir perfectus est. quae perfectio vel sola, vel praecipua ex virtute conficitur, apud eum quidem, inquisitionem mortalem utilissimam censeo, tum quia vitae unicum ornamentum, tum quia prima scribentis intentionem sequitum (Rerum senilium libri, IV, 5. Cito por Operum Francisci Petrarchae Florentini, Basileae, per Henrichum Petri, 1554, tomo II, fols. 868 y 869). Sobre la alegoría petrarquesca, véanse Ardissino (1990-91) y Fenzi (2003: 553-587). Villena, en cambio, desplaza el sentido moral general al servicio del estamento nobiliario: lo importante no es tanto presentar a Eneas como un modelo de virtud humana sino como un modelo de principes y nobles. Así dice en la glosa donde comenta un discurso de Eneas a los suyos: «En estos dezires muestra doctrina a los principes e grandes señores quando se veen en algunas afruentas con sus gentes, cómo las deven conortar e animar porque non desmayen (...). E si la doctrina moral esto se quisises bolver, fermosas exposiçiones fazerse podrían, que por non dilatar estas glosas non entrincar la materia donde escusar se puede, se dexa. Basta a los príncipes dar expecífica doctrina de la consolaçión del discreto príncipe Eneas.» (Cátedra (1989': 211, gl. 210. Las cursivas son mías.) Nótese especialmente que mientras que para Petrarca, Eneas es «vir fortis ac perfectus», en Villena es ante todo «el discreto príncipe Eneas».

57. Cátedra (1989ª: 48, gl. 45).

58. Miguel Prendes (1998: 85).

59. Sirva, por ejemplo, el caso de Luis Zapata, en cuyo prólogo al Carlo Famoso (1566) advierte que «junté y allegué muchas relaciones, muchos papeles y memoriales, y muchos libros, 
de esta ascensión lectora, el que sirve a la alabanza individual, pero que cabe trascender, como consecuencia del uso de los «colores rethoricales» que dan entidad a la alegoría villenesca, para culminar en un encomio general de las buenas costumbres que don Enrique identifica con la intención autorial virgiliana. Con su traducción y glosas, en resumidas cuentas, Villena, en la estela de los comentarios alegóricos medievales, rotura el camino a una tradición épica que no se preocupa (al menos en este estadio) tanto de la forma cuanto del sentido, propugnando una continuidad que incide antes en los beneficios (la fama y la memoria) de los gobernantes gracias al merecido pago de una poesía épica que busca ensalzar al sujeto mediante una narración histórica aderezada con las técnicas poéticas. La lectura alegórica complementa y culmina esta visión de la escritura histórica, porque, en tanto que plantea su naturaleza ejemplar, dirige al género hacia la lectura política como espejo de príncipes. Las nuevas crónicas poéticas defendidas por el de Aragón están, como la Eneida virgiliana, al servicio del poder: como ella, ofrecen una imagen idealizada de la caballería al tiempo que están destinadas a completar su formación.

En este sentido, con Weiss, ${ }^{60}$ cabe concluir que Villena antecede a los teóricos del XVI porque su obra aúna creación y reflexión teórica y en el caso particular que nos ocupa defiende una idea, vigente en el siglo siguiente, sobre los modos poéticos de la escritura histórica como relación verdadera pero idealizada, que privilegiará una visión histórica y superior de la épica. Al igual que la Eneida, las «ystorias» y las "corónicas» (pues Villena no distingue entre ambas acepciones) ponen la verdad al servicio de la fama de los poderosos. Pero se trata de una verdad pasada por el filtro de la retórica y, por ello, tolera la inserción de "fingimientos», de alteraciones de la verdad histórica, que el autor cifra en diversas ocasiones en el recurso al ordo artificialis. No hay, aparentemente, contradicción en la escritura histórica y poética (que es suma y culminación de los saberes científicos) de Villena porque posiblemente don Enrique considera que la «ystoria» es principalmente una narración verosímil. ${ }^{61}$ Ésta sirve del mejor modo posible a la recordación de la fama póstuma de los poderosos, ayuda a construir una imagen idealizada y metafórica del poder político y del estamento nobiliario, y establece la relación de estrecha interdependencia entre el poeta y el poder, al modo virgiliano. Al cabo, pues, como lo será la épica histórica del

que cual un poco, y cual otro poco, trataban de todo lo que yo deseaba» que encauzó por una narración poética por ser la poesía "cosa en que los grandes hechos pueden (como yo destos pretendo) ser más celebrados», si bien ello no oculta que en su dedicatoria del poema al monarca busque (sin éxito) la restitución personal de su honor y la liberación de su encarcelamiento. Cito por la edición príncipe Carlo
Famoso de don Luys Çapata a la C.R.M. del Rey don Phelippe Segundo nvestro señor, Valencia, en casa de Ioan Mey, 1566. Parecidos motivos empujarían también, por cierto, a Alonso de Ercilla a escribir su poema de "historia verdadera y de cosas de guerra». (Cito por la edición de Lerner, 1993: 69).

60. Weiss (1990: 82).

61. Weiss (1990: 92). 
siglo siguiente, de las teorías villenescas se sigue una visión de un tipo de escritura poética de naturaleza histórica, gremial y con una finalidad política. No a todos corresponde, como insiste Villena aquí y allá, la escritura de las gestas de los poderosos, sino sólo a los mejores, a los versados en las ciencias y las letras; del mismo modo, la ecuación se completa en el ámbito de la recepción ya que, al considerar que estas crónicas poéticas son, gracias a la lectura alegórica, espejos que iluminan a la caballería y al regimiento de la cosa pública, el elitismo autorial se completa con unos «leedores» que pertenecen a la élite aristocrática. Éstos no sólo son los mejores socialmente: con la traslación al romance de la gran obra de la Clasicidad, Villena espera contribuir a la formación de esos nobles para que, a la postre, resulten ser los mejores en virtud y conocimiento. Este elitismo cultural y nobiliario que rezuma la traslación y glosas de Enrique de Villena no resulta ser tan distinta de la afirmacion hecha por el Pinciano de que «a leer una épica no se acomoda el vulgo»: ${ }^{62}$ ambas, de hecho, responden a una misma visión, de amplia difusión en el Cuatrocientos y en el Quinientos espańol, de la educación de la clase regia y militar en unos textos particulares, entre los que la épica ocupa, indudablemente, un lugar privilegiado.

\section{Historia y poesía en Juan de Mena}

La visión política de la primera traslación en romance castellano de la Eneida aducida por el de Aragón, aunque pergeñada aún en un armazón medieval, constituye una cala inexcusable para seguir el «virgilianismo político» de la épica quinientista desde una perspectiva estrictamente hispana. Interesa en particular por ser la primera traslación castellana de un texto latino de tanto prestigio y por la forma cómo don Enrique adapta interesadamente la ideología virgiliana a su momento y cultura. De la notoriedad y reconocimiento de esta traducción poco puede decirse hoy que no sepa el lector. Baste recordar que el Marqués de Santillana, a cuya sugerencia se redactaron la traducción y las glosas, leyó a Virgilio en la versión de Villena, y Juan de Mena lo sitúa en el círculo de Febo como único representante de los sabios contemporáneos y lamenta la dispersión y la destrucción de su biblioteca. Resulta imposible realizar aquí una andadura detenida por todos los textos cuatrocentistas que usaron a Virgilio o que abundaban en una consideración de la historia y de la poesía cercana a las presuposiciones villenescas. Me interesa detenerme, muy brevemente y a modo introductorio, en la aportación hecha por Juan de Mena al tema de estas páginas, en especial en la traslación al romance de la Ilíada y en el Laberinto de fortuna, porque fue un poeta tenido en gran estima por los intelectuales de su 
generación y de la siguiente y acabó convertido, según el Brocense, en el primero que había «ilustrado la lengua castellana». ${ }^{63}$ Interesa Mena, y mucho, para la idea de la épica en el Quinientos: el mismo Sánchez de las Brozas proponía que el Laberinto era poesía épica, ${ }^{64}$ y no es extraño encontrar ejemplos en la épica española del período cuya inspiración procede del vasto constructo alegórico meniano en loor del «muy prepotente don Juan el segundo», al que el poeta tilda de "César novelo». ${ }^{65}$

La obra de Mena, por otra parte, evidencia, con el relevo generacional, una evolución respecto de lo planteado en la obra de Villena o el Marqués de Santillana hacia una valoración de los clásicos sujeta a nuevos impulsos y a un conocimiento mayor de los textos, procurado gracias a una relación cada vez más frecuente e intensa con los escritores italianos, que tendrá en la recuperación de la Ilíada homérica medieval en la península un momento clave y altamente simbólico. La sustitución de los viejos maestros redundará, además, en un interés cada vez mayor por los recursos estilísticos y expresivos de los autores clásicos, más allá del eminente valor histórico y moral que la generación de Villena buscaba en sus textos, y los intelectuales de la época de Mena se acercarán de una manera reverente al modelo elocutivo latino. Pese a todo, obviamente, subsisten algunas preocupaciones y una de ellas, justamente, nos interesa aquí en particular: la veracidad de lo narrado y las potencialidades de la poesía como subsidio del olvido.

Sostiene acertadamente Weiss ${ }^{66}$ que la relación entre historia y poesía era tema controvertido, ya que, en principio se consideraba que eran opuestas. Isidoro de Sevilla había legado una definición de larga fortuna, ${ }^{67}$ que Mena repetiría en una glosa a La coronación, que establecía que la verdad histórica estaba reñida con los principios ficcionales de la poesía. La distinción viene, como veíamos anteriormente, de antiguo y la encontramos documentada en Servio.$^{68}$ El comentarista virgiliano acabará acuñando la idea, que despunta aquí y allá a los largo de sus enarraciones, de que aunque la épica se funda en la historia (y, por ende, apunta a la verdad)

63. En Las obras de Juan de Mena declaradas y enmendadas, «Al lector", 1582, s. p. Las palabras del Brocense se inscriben en la polémica entorno a este autor. Según Morros (1998: 229-30), la polémica sobre Mena, por parte de sus críticos italianos, se explica por «los rencores hacia la nación que los había sometido" y que Lida explica (1950: 335) por la oposición entre dos formas distintas de entender a los clásicos a lo largo del Cuatrocientos, de forma que los humanistas italianos «levantan su propio ideal artístico» como norma para oponer (y menospreciar) las aportaciones del «prerrenacimiento» castellano al ideal artístico y erudito italiano.

64. «Dicen algunos que es poeta muy pesado, y lleno de antiguallas; y dicen esto con tanta gravedad, que si no les creemos parece que les hacemos injuria: y no advierten que una poesía heroica como ésta, para su gravedad, tiene necesidad de usar de palabras y sentencias graves y antiguas para levantar el estilo", en op. cit, s.p. 65. Laberinto de Fortuna, 1 a y e. Cito por la edición de Carla de Nigris (1994: 65).

66. Weiss (1990: 77-78).

67. Se encuentra ya en Lactancio, quien sanciona que los poetas deben adornar su historia con invenciones, si bien estos fingimientos deben ser utilizados con precaución para no inducir a engańo, de lo que se deduce que «Vera sunt ergo quae loquuntur poetae, sed obtentu aliquo specie velata» (Div. inst., I, 11, 34).

68. Vid. supra, n. 49. 
no debe hacerlo sino veladamente. ${ }^{69}$ Por lo tanto, la labor del poeta es manipular la historia según las reglas de la poética y, a partir de algunas insinuaciones servianas, la «alegoría histórica» acabara erigiéndose como uno de los principios fundamentales de la escritura épica, como ya atestiguaba la labor de Villena. La alegoría, por tanto, deviene una licencia poética de primer orden, un obligado peaje en la escritura épica (y la razón por la que Lucano no fuera considerado un autor en la nómina de los poetas sino de los historiadores, ya desde Quintiliano), ${ }^{70}$ que no invalida la veracidad de lo narrado sino que la oculta o la disimula bajo la oscuridad del velo poético. La raigambre antigua de esta distinción, con censura incluida de aquellos que, como Lucano, se habían atrevido a infringirla, era de sobras conocida por los autores castellanos cuatrocentistas. Y Mena la explota concientemente en el $\mathrm{La}$ berinto, como ya se percataría Hernán Núnez en sus glosas, ${ }^{71}$ cumpliendo así con su tarea de poeta, que prima sobre la de historiador. ${ }^{72}$ Ahora bien, como también advirtiera Mena cuando se dispone a traducir la Ilias latina, tomándola como obra de Homero, tal distinción era difícilmente sostenible. En la defensa de Homero frente a los ataques de Guido delle Colonne en la Historia destructionis Troiae se ve en la obligación de restituir el nombre del antiguo poeta y, para ello, aduce el carácter histórico de su narración del desastre de Troya. Porque, para Mena, Homero es poeta e historiador por igual, sólo que su forma de narrar la historia obedece a las fórmulas de embellecimiento que tanto contribuyen, como sancionara Villena, a la restitución del olvido de las grandes gestas y a la fama póstuma de las mismas de una forma que no resulte demasiado evidente:

E pongamos que estos hechos fueron assí, o más allende de quanto assí: ¿Pudieran más durar de quanto naturaleza la sostuvo? Cierto no, si el claro ingenio de Homero no los desnudara de las ciegas tinieblas de olvidança, a las quales la antigüedad tenía offrecidos, dando a todos estos lo que por naturaleza a todos negades, es a saber: la biva y perpetua inmortalidad... ${ }^{73}$

Los poetas, por lo tanto, crean la verdad, la verdad que cuenta, la que no se olvida, la que da la inmortalidad. Por ello, el poeta es quien verdaderamente construye la fama de aquellos a los que celebra y esa es precisamente una de las ideas que vertebran el Laberinto y su celebración de poder regio: la responsabilidad del escritor es, pues, enorme y debe tratar la materia histórica con sumo cuidado. ${ }^{74}$ De ahí que su

69. "Per transitum tangit historiam, quam per legem artis poeticae aperte non potest ponere» (Serv., ad Aen., I, 382).

70. Quint., Institutio oratoria, I, 10, 90.

71. Véase la glosa a la octava 279. Remito a la edición electrónica de Weiss y Cortijo.

72. Véanse las palabras de Lida (1950: 45): "Como poeta se siente supeditado únicamente a la eficacia estética, y exento de las leyes que rigen otros dominios.»
73. La Yliada en romance, Prohemio de Juan de Mena al rey don Juan el Segundo (Cito por la edicion de Riquer, 1949: 40).

74. Más adelante, en el mismo Prohemio, Mena aducirá el célebre lamento de Alejandro por carecer de un Homero que cantara sus heroicidades: «et dixo allí que sería bien contento de trocar la prosperidad que los dioses le tenían aparejada et partir mano de la parte que los dioses en el cielo le pudiessen dar por aver un tan 
conciencia, mientras se acerca a las ruedas de Fortuna, le dicte «que por amigo nin por enemigo,/ nin por amor de tierra nin gloria, non finjas lo falso nin furtes estoria, / mas di lo que oviere cada qual consigon. ${ }^{75}$ La historia (o la histórica poesía que sirve al poder real, porque eso es el Laberinto al fin y al cabo), de nada sirve, como aducirá Hernán Núñez en su glosa, si es falsa:

...que ningund affecto te constrińa a dezir otra cosa de la verdad en la parte de tu obra que fuere histórica, porque, como dize Polybio en el primero de los Annales, asy como en el hombre sy le sacan los ojos todo lo otro no vale nada, asy la historia sy le quitas la verdad es inútil y syn provecho; y Dionysio Halicarnáseo en el prohemio de las Antiguedades romanas: 'Y principalmente a los escriptores de historias en las quales tomamos a cargo de poner la verdad'; y Plutarcho Cheroneo en la Vida de Cimón: 'Y no por eso quitaremos nada de la verdad de la historia por congraciar'; Strabón Cappadocio en el primero de la Geographía: 'El fin de la historia es la verdad'; y Herodiano en el principio de sus Historias protesta que escrivirá verdad y que no fingirá cosa alguna por lisonjear, como otros hizieron.

Sólo la verdad, adornada con los atributos que le confiere el poeta, cumplirá con la voluntad de otorgar la fama a los grandes héroes contemporáneos y restituirá de las oscuras tinieblas su memoria, que en este caso, con un aliento inequívocamente épico que parte indudablemente del modelo de Lucano, se encauza hacia el «loor de los reyes de España la clara», o, más concretamente, de Juan II y su valido, Álvaro de Luna. ${ }^{76}$ Así lo reconoce Hernán Núñez de Guzmán en la glosa 123f: «De manera que se podrán dezir heroycos Lucano, que trató de las guerras civiles entre César y Ponpeyo, que fueron entonces los principales y más bellicosos cavalleros entre los romanos, y Estacio, que escrivió en el 25 Achilleyda /[f. 68v] de Achilles, al qual él llama héroe en el principio della. Heroicos Vergilio, Silio Itálico, Valerio Flacco, Claudiano y otros muchos poetas, asy latinos como griegos, y heroico se podrá llamar Juan de Mena, porque trata aqui de los hechos de muchos claros varones., ${ }^{77}$

Y, volviendo al principio, cabe recordar, con Hernán Núñez y el Brocense, que pese al ropaje alegórico del Laberinto, pese al uso de fuentes clásicas mediadas por otras medievales, el poema rezuma epicidad por lo cuatro costados: épico es el concepto de la alegoría de que se sirve Mena para su celebración del rey, épico su mensaje e igualmente épico su concepto de la historia como verdad embellecida. Bastará, también, que recuerde el lector que el círculo de Marte es el más extenso de cuantos describe la obra, lo que redunda en la percepción, de sobras difundida en la época, de que la péńola es la que mejor sirve a la espada. ${ }^{78}$ Juan

sumo et alto lector de sus fechos como Achiles avía avido en Homero.» (Cito por la edición de Riquer, 1949: 42).

75. Laberinto, $61 \mathrm{e}-\mathrm{h}$.

76. Laberinto, $220 \mathrm{f}$.

77. Cito por la edición de Weiss y Cortijo. Las cursivas son mías. Agradezco al profesor Julian Weiss que me señalara este pasaje.

78. Es idea defendida también por Villena en los Doze trabajos de Hércules. Sobre la relación del círculo de Marte con el proyecto épico de Mena, vid. Clarke (1973: 40). 
de Mena reviste su proyecto épico en el Laberinto de historia y de verdad, porque así siente el presente, tal como lo sentirán los poetas épicos del siglo posterior, ${ }^{79}$ si bien, pese a la recurrencia continua a la verdad, la versión poética de la historia épica procede ante todo por una selección de los acontecimientos narrados, como ya señalara el Comendador Griego en sus glosas.

\section{Verdad y alegoría en la épica quinientista}

La misma libertad de que hicieron uso los intelectuales del Xv en su uso de las fuentes clásicas (así como las más modernas, hijas del humanismo italiano) es la que ampara, a mi juicio, la actitud que demuestran los poetas épicos del Quinientos español. La idea de que la realidad de la España imperial no tenía necesidad de ropajes ficcionales sino que podía aducirse directamente, sin embelecos, mediante una relación verdadera que no por ello dejara de ser poética la encontraron ya, aunque, ciertamente, con sesgos diferenciales, en la tradición del siglo precedente. No he pretendido hacer aquí un estudio de la obra de Villena y de Mena per se, sino que la intención de estas páginas ha sido la de explicar la épica histórica de la Espańa quinientista a la luz de la tradición hispana precedente, que debe forzosamente matizar la presencia y utilización de los grandes modelos clásicos según los patrones humanistas. La reiterada insistencia villenesca en que la historia se escriba al virgiliano modo y la preocupación constante de Mena por la verdad se plantean en el marco de un complejo debate sobre la historiografía y la relación poética, ya abordada en el mismo siglo (por ejemplo entre la concepción más medieval de un Villena y la más renacentista de un Pérez de Guzmán). Como sostiene Cátedra, una edad considerada heroica (léase la de Juan II a ojos de Mena, la de los Reyes Católicos a la vista de Juan del Encina, Pulgar o Juan Barba, o la de Carlos V y Felipe II cuando la contemplan sus poetas épicos) es también histórica y, por ello, «conducente al engrandecimiento y al mantenimiento del statu quo social y político». ${ }^{80}$

Esa es, justamente, la razón que explica la divergencia entre la praxis épica española (y portuguesa) y la italiana en el xvi: la conciencia de vivir una época dorada, similar a la que conociera Roma bajo Augusto, revivida a través de la lectura de Virgilio, Ovidio, Lucano, Livio, Salustio, filtrada por un contexto cultural, el del xv, muy distinto del de la Italia del humanismo, que motivaría una aproximación a los textos antiguos de muy diverso cuño. Los intelectuales del Cuatrocientos buscaron, a su modo y con las herramientas

79. Aunque, irónicamente, con el tiempo y de la mano de su propio comentador, Hernán Núñez, la ideología regia del Laberinto será subvertida en un reconocimiento de la labor de los Reyes Cató- licos, en un intento de dejar en las tinieblas el oscuro período (según la propaganda del momento) del reinado de Juan II. Vid. Weiss (1993).

80. Cátedra (1989º : 132). 
de que disponían, la confirmación primero de una conciencia de clase que más tarde se encauzaría en el elogio culminante de la monarquía de los Reyes Católicos por medio de la manipulación de textos que servían para justificar y legitimar, a través de la auctoritas, unos condicionantes sociales y políticos. ${ }^{81}$ El humanismo italiano, al carecer de ese presente, proyectaba en sus letras, en cambio, el deseo de reencontrarse con un viejo y acariciado ideal que aspiraba a la restitución de los viejos valores imperiales en la Roma contemporánea. ${ }^{82}$ Eso mismo que buscaban los intelectuales legos del xv, nobles o curiales, en las traducciones vernaculares de los autores antiguos, es decir, la demostración y justificación de los valores de una nueva nobleza (la necesaria unión de las armas y las letras, la ejemplaridad moral y cívica de los textos clásicos, y de algunos modernos, $y$, por ende, su utilidad práctica) y de una nueva monarquía potente y centralizada, buscarían los poetas épicos del xvi en los modelos clásicos y modernos cuando pretendían su reescritura e hispanización a la luz de los acontecimientos recientes. Pero, para ello, ni les bastaron las lecturas de los críticos italianos ni acusaron con tanta acritud las polémicas literarias del siglo en torno a la cuestión del romanzo y si éste era o no épica. Porque, mientras unos se preocupaban de forma casi exclusiva por cuestiones teóricas, ${ }^{83}$ los otros usaron de una mayor libertad y concibieron la épica, en el sentido más tradicional y sin empacho, como el género de la alabanza del poder, tal como Virgilio lo cifrara en la Eneida. Una muestra evidente de esta percepción distinta se encuentra en la relación evidente que existe en las teorizaciones de la épica formuladas por los propios poetas en España y en la casi total inexistencia de tratados al modo aristotélico. Salvo en el caso de Trissino y de Tasso, la mayor parte de autores que se preocuparon por teorizar la épica en la Italia del Quinientos no eran poetas sino especialistas del estudio de las letras; en la mayoría de casos, asimismo, prima el molde teórico del tratado de poética que, erigido sobre el andamiaje aristotélico, busca hacer abstracción de un fenómeno literario que únicamente puede explicarse desde el contexto cultural y político. Una prueba muy evidente es cómo, paulatinamente, la reflexión

81. Para la presencia de elementos clásicos en las crónicas de finales del xv, en especial en la de Pulgar, así como en su galería de retratos, cuyos hipotéticos ecos de Plutarco importan mucho menos que la conciencia genealógica y nobiliaria, véase sobre todo Pontón (2008). Agradezco al autor que me llamara la atención sobre este particular.

82. Ese espíritu es el que se encuentra en la raíz, por ejemplo, del Africa de Petrarca o, ya a principios del siglo Xvi, de la Christias de Vida.

83. Lo que Rico $(1997: 94,97)$ ha denominado «la torre de marfil»: «Poliziano supone el punto de llegada teórico (...) el punto en que las aportaciones fundamentales de los studia humanitatis están ya consolidadas en la avenida mayor de la civilización y los humanistas italianos se han ganado el derecho a retirarse a las torres de marfil de la investigación especializada; el punto en que la filología clásica deja de ser el motor principal de la cultura y se convierte para siempre en una técnica auxiliar de la historia y la crítica italiana, sin influir salvo en una parva medida en el rumbo de otros saberes. (...) La evolución en un sentido es involución en otro: la maestría filológica arrincona el sueño de refundar la civilización». 
y la lectura de Virgilio se aleja de los frentes retóricos y morales del primer humanismo para concentrarse en el ajuste del modelo al marco aristotélico. La fractura evidente entre el ámbito de la escritura y el de la reflexión teórica, en Italia, sólo llegaría a soluciones de consenso a finales de siglo, justamente con la obra de Tasso. Que ello es así lo demuestra que el modelo tassesco se importará a España, desplazando la reflexión hacia cauces distintos de los que hasta aquel momento habían sido predominantes.

Pero mientras estos no ocurría, la épica en España no sólo era uno de los géneros más frecuentados; al mismo tiempo, eran casi exclusivamente los mismos poetas quienes teorizaban al respecto y nunca en tratados sistemáticos, llegando a conclusiones muy parecidas entre ellos y que colisionaban con las ideas expuestas en la preceptiva italiana. Así, y remito nuevamente a Vega y a las páginas iniciales de este estudio, ${ }^{84}$ los poetas españoles que escriben épica «histórica» (la épica sacra, como apuntaba arriba, constituye en este sentido capítulo aparte ${ }^{85}$ coinciden en una preocupación constante por rescatar del olvido las gestas de los héroes nacionales del pasado y del presente, por la veracidad de lo narrado, por justificar el tratamiento de los hechos aduciendo que previamente se han documentado con rigor o bien que ellos mismos han sido testigos o participantes activos en los que hechos que relatan. Al cabo, se presentan como poetas y «coronistas» (y así lo leemos tantas veces en el poema de Ercilla, por ejemplo) que quieren ensalzar con la pluma los logros conseguidos en la guerra. Sus poemas, siempre dedicados a monarcas y nobles, cumplen, a sus ojos, una función social, que no se cifra en el deleite sino en la ejemplaridad moral y civil, al igual que la Historia, con la que compartirán lugar en los anaqueles nobiliarios. Su defensa de la verdad y su renuencia a la ficción (aunque necesaria para cumplir con el modo poético) apuntan ambas en esta misma dirección, que es la misma que Providencia recomendara al Mena del Laberinto. Pero, como en el caso de Mena, es evidente que la reescritura histórica procede por selección y que la inserción en el marco mitificante de la épica obliga, como ya advirtiera Villena, a ensalzar al sujeto, porque ese es el elemento principal que le confiere carácter modélico y ejemplar. Tras el escudo de la verdad late, no lo olvidemos, la voluntad de presentar a Espańa como la única y legítima heredera de la Roma imperial y a sus monarcas (y, por extensión, a sus nobles principales) como los sucesores de los héroes clásicos y los continuadores de los medievales defensores de la fe. ${ }^{86}$

Creo que a esta preocupación por la verdad y al sentir común de que no cabe empañar la narración de materia presente con embelecos ficcionales, por otra parte, responde el progresivo abandono de la narración alegórica, lo que permite

84. Vega (2010).

85. Vid. supra, n. 16.

86. Ambas imágenes simbólicas del poder sir- vieron para el elogio propagandístico de Carlos V, que tanto aparecía como nuevo César, ataviado all'antica, y como nuevo Carlomagno. 
ceñirse de una forma más directa a la historicidad de su materia. ${ }^{87}$ Cierto es que la idea de la alegoría épica seguirá, pese a todo, muy vigente en el Quinientos ${ }^{88} \mathrm{y}$ así lo sancionan de una manera evidente tanto los empeños de los comentaristas ariostescos por dotar de una lectura moral al Furioso, en respuesta a los ataques y censuras de moralistas, como el deseo finisecular de Torquato Tasso (al arrimo de las lecturas alegóricas de Virgilio) de hacer preceder su Gerusalemme liberata de una Allegoria expresamente redactada para encauzar la praxis y la exégesis épicas por las sendas de la ortodoxia cristiana. O, en España, servirá también para dirimir las censuras de los moralistas contra las exageraciones y patrañas de las novelas de caballerías. ${ }^{89}$ La narración alegórica, tan en boga en el período medieval, vivirá un proceso de involución, es decir, abandonará el terreno de la escritura poética para convertirse de nuevo en una herramienta exclusivamente crítica con la que ennoblecer la materia de una obra y hallará acomodo, pues, en prólogos, dedicatorias y enarraciones ${ }^{90} \mathrm{o}$, en algunos casos, en pasajes estrictamente calificables de «alegóricos»: es decir, quedarán circunscritos, en el caso de la épica histórica, a las descripciones de templos y palacios de la Fama y similares. En ellos, los poetas épicos españoles llevan a cabo una revisión interesada

87. En el caso español, sólo tenemos constancia de la existencia de un poema alegórico, el Hércules animoso de Juan de Mal Lara y no deja de ser significativo, a tenor de lo apuntado arriba, que se deba a la pluma de un humanista.

88. Vid. Murrin (1980). La atención alegórica de la épica no revestiría unanimidad en el Quinientos. Aunque evidentemente desplazada por una preocupación mayor por las cuestiones gramaticales y enarrativas que redundarían en una aproximación más literal a los textos, subsitiría todavía la alegoría como un modo de elevar los valores filosóficos y morales de la poesía, en especial de la antigua. El caso de Virgilio sigue siendo paradigmático en este sentido. Basta contrastar, por ejemplo, los comentarios de Juan Luis Vives, que en pleno Renacimiento seguía inclinándose por la alegoría (posiblemente al amparo de la lectura agustiniana), con la interpretación visual de un humanista anterior, Sebastian Brandt, que la ignoraría. Así, si Vives detecta más «loci allegorici» en la obra virgiliana de las que señalaba Servio ("Accedit buc quod res ipsae plerisque in locis satis testantur, non simpliciter dici, sed figurate; quo magis mirror Servium Honoratum nullas allegorias admittere nisi de agris deperditis: quae aliis multis de rebus manifestissimae sunt», "In allegorias Bvcolicorvm Vergilii Praefatio», en Juan Luis
Vives, Antología de textos, València, Universitat de València, 1992, p. 86.), la interpretación visual que ofrece Brandt de la célebre Bucólica IV, por ejemplo, parte de la lectura histórica formulada por Servio (conforme a la cual el «puer» virgiliano es hijo del cónsul Polión) e ignora claramente el mesianismo largamente atribuido al poema.

89. Vid. Gagliardi (2010).

90. Dice por ejemplo Francisco Núńez de Oria en la dedicatoria a don García de Mendoza que precede a sus Lyrae heroicae libri (1581) que bajo el pretexto de las luchas, las guerras y los amores podrán sacarse muchos ejemplos de las buenas costumbres y que bajo el pretexto de las cosas humanas se entienden las morales: "In quo sub praetextu certaminum, bellorum, congressuum, amorum, multa exempla ad optimos mores, \& beatitudinem, multa ad sacrae historiae cognitionem spectantia cospiciuntur. (...) Haec poësis duo praese fert, tum vt sub praetexta humanarum rerum, moralia, \& ea quae ad recte beateque viuendum conferunt, subintelligantur: quemadmodum in cuiusque libri initio, ex Allegoria innotescit: tum vt praeclara trophaea a Impe. Carli. V. \& eius filii Philippi, \& illustrium Hispania...» (Lyrae Heroicae libri quatuordecim, Salmanticae, apud haeredes Mathie Gastij, 1581, fols. 4 y 4v.) 
de la historia pasada y reciente de Espańa, en un sentido político de defensa del poder monárquico imperial de los Austrias que mucho debe a los planteamientos narrativos e ideológicos de Mena, al cabo, un "clásico» castellano y, como tal, digno de imitación. ${ }^{91}$ La alegoría épica, y hablo sólo del Quinientos español, se licúa, se desvanece ante el voluntario y premeditado empuje de unos poetas que buscan ensalzar el presente de la patria a través de la guerra. Pero cuando aparece, aunque sea en momentos puntuales o en paratextos que pretenden dotar a las obras de una pátina filosófica y moral, se erige en un garante de la ideología monárquica y militar. $\mathrm{Y}$ es preciso reconocer que la evidente propaganda política a favor de la monarquía que Mena hilvana en el Laberinto, su complejo uso de las fuentes clásicas (en especial de Virgilio, Lucano y Ovidio) imbricadas con otras más claramente medievales, nos sitúan de lleno en la particular forma cómo los poetas épicos de la España imperial se sirven de los modelos para reconducirlos al elogio político del soberano o de algunos de sus nobles. A fin de cuentas, los poetas épicos del Quinientos que escriben épica histórica toman antes en la senda abierta por sus compatriotas del Xv que lo propuesto por los humanistas y preceptistas italianos. Su idea de la épica (al arrimo de la Eneida) coincide más con las pretensiones de Villena y Mena que con las de Minturno o Trissino: ven ella un género gremial, escrito por aquellos que mejor pueden guardar la memoria y establecer la fama póstuma de los grandes hombres y escrito para los mejores, que lo son supuestamente en virtud y por su condición social. Y eso sólo puede hacerse por medio de una poesía que sea histórica, de forma que sus obras sean la plasmación poética de la verdad, de una verdad que puede corresponder, sin problema alguno, con la mitificación de un presente que se percibe como heroico. Para ellos, además, la épica sigue siendo un género doctivo, destinado a la lectura e iluminación específicamente del estamento regio, nobiliario y militar y, sobre todo, pues muchos son poetas y soldados, conciben la escritura épica como elogio del poder y, a la postre, como una forma más de servicio a la patria, a la que defienden con la pluma y la espada.

91. Lida (1952: 280) apunta que todo el $L a-$ berinto meniano puede ser considerado una gran Casa de la Fama y señala sus raíces medievales. 


\section{Bibliografía}

Alcina, J. F. y Salvadó, J., La biblioteca de Antonio Agustín. Los impresos de un humanista de la Contrarreforma, Alcañiz, Instituto de Estudios Humanísticos, colección Palmyrenus, 2007.

Ardissino, Erminia, «Petrarca e l'allegorizzazione dell'Eneide», Atti dell'Istituto Veneto di Scienze, Lettere ed Arti, tomo CXLIX (1990-91), 239-266.

Ariani, Marco, Petrarca, Roma, Salerno Editrice, 1999.

Asensio, Eugenio, «España en la épica filipina», Revista de Filología española, 33 (1949), 66-109.

Avalle-Arce, J. B., La épica colonial, Ansoáin, Universidad de Navarra, 2000.

Barrio, José Antonio (ed.), Fernán Pérez de Guzmán, Generaciones y semblanzas, Madrid, Cátedra, 1998.

Carballo Picazo, Alfredo (ed.), Alonso López Pinciano, Philosophia antigua poética, Madrid, CSIC, 3 vols., 1953.

Carr, Derek C., "Pérez de Guzmán and Villena: A Polemic on Historiography?», en J. S. Miletich (ed.), Hispanic Studies in Honor of Alan D. Deyermond. A North American tribute, Madison, Hispanic Seminary of Medieval Studies, 1986, 57-70.

Cátedra, Pedro M., «Enrique de Villena y algunos humanistas», en V. García de la Concha (dir.), Academia Literaria Renacentista, III. Nebrija y la introducción del Renacimiento en España, Salamanca, Ediciones Universidad de Salamanca, 1983, 187-203.

Cátedra, Pedro M., Enrique de Villena. Traducción y glosas de la Eneida, 2 vols., Salamanca, Diputación de Salamanca, 1989.

Cátedra, Pedro M., La historiografía en verso en la época de los Reyes Católicos. Juan Barba y su Consolatoria de Castilla, Salamanca, Universidad de Salamanca, 1989.

Cátedra, Pedro M., "El sentido involucrado y la poesía del siglo xv. Lecturas virgilianas de Santillana, con Villena», en A. Menéndez Collera y V. Roncero López (eds.), Nunca fue pena mayor (Estudios de Literatura Española en homenaje a Brian Dutton), Cuenca, Ediciones de la Universidad de Castilla-La Mancha, 1996, 149-161.

Chevalier, Maxime, L'Arioste en Espagne (1530-1650). Recherches sur l'influence $d u$ "Roland furieux», Bordeaux, Institut d'études ibériques et ibéro-américains de l'Université de Bordeaux, 1966.

Chevalier, M., Lectura y lectores en la España del siglo XVI y XVII, Madrid, Ediciones Turner, 1976.

Сirot, George, "Coup d'œil sur la poésie épique du Siècle d'Or», Bulletin Hispanique, 48 (1946), 294-329.

Clarke, Dorothy Clotelle, Juan de Mena's Laberinto de Fortuna: Classic Epic and Mester de clerecía, Valencia, Romance Monographs, 1973. 
Davis, Elizabeth B., Myth and Identity in the Epic of Imperial Spain, Columbia and London, University of Missouri Press, 2001.

DAvis, Elizabeth B., «Épica y configuración del canon en la poesía española del Siglo de Oro", en B. López Bueno (ed.), En torno al canon: aproximaciones y estrategias, Sevilla, Universidad de Sevilla, Secretariado de Publicaciones, 2005, 317-332.

Delgado, Feliciano, La vida de Virgilio de don Enrique de Villena, Córdoba, Ediciones Escudero, 1979.

Deyermond, Alan, «La ideología del Estado moderno en la literatura española del siglo XV", en Rucquoi, Adeline (coord.), Realidad e imágenes del poder. España a fines de la Edad Media, Valladolid, Ámbito, 1988, 171-193.

Di Camillo, Ottavio, El Humanismo castellano del siglo XV, Valencia, Fernando Torres Editor, 1976.

Ercilla, Alonso de, vid. Lerner.

Espinosa, Nicolás, La segunda parte del Orlando, con el verdadero suceso de la famosa batalla de Roncesvalles, fin y muerte de los doze Pares de Francia: dirigida al muy Ilustre Señor Don Pedro de Cenetllas..., Amberes, Martín Nucio, 1557.

Fenzi, Enrico, Saggi petrarcheschi, Firenze, Cadmo, 2003.

Folger, Robert, Generaciones y semblanzas. Memory and Genealogy in medieval Iberian Historiography, Tübingen, Gunter Narr Verlag, Romanica Monacensia, 2003.

GaGliardi, Donatella, «Entre fábula, épica e historia. Definiciones del género caballeresco en la España del siglo Xvı», en M. J. Vega y L. Vilà (eds.), La teoría de la épica en el siglo XVI (España, Francia, Italia y Portugal), Vigo, Academia del Hispanismo, 2010, 241-267.

Gallego Morell, Antonio (ed.), Garcilaso de la Vega y sus Comentaristas, Madrid, Gredos, 1972.

Gómez Moreno, Ángel, España y la Italia de los humanistas, Madrid, Gredos, 1994.

Green, Otis H., "Fingen Los Poetas - Notes on the Spanish Attitude toward Pagan Mythology», en The Literary Mind of Medieval \& Renaissance Spain, Lexington, The University Press of Kentucky, 1970, 113-123.

Greene, Thomas M., The Light in Troy. Imitation and Discovery in Renaissance Poetry, Yale, Yale Univeristy Press, 1982.

Herrera, Fernando de, Obras de la Garcilasso de la Vega con Anotaciones de Fernando de Herrera. Al ilustrissimo i ecelentissimo Señor Don Antonio de Guzmán, Marqués de Ayamonte, Governador del estado de Milán i Capitán General de Italia, En Sevilla, por Alonso de la Barrera, 1580.

Jiménez de Ayllón, Diego, Los famosos y heroicos hechos del ynvencible y esforçado caballero, honra y flor de las Españas, el Cid Ruy Díaz con los de otros varones ilustres d'ellas, no menos dignos de fama y memorable recordación en octava rima, por Diego Jiménez de Ayllón, en Anveres, en Casa de la Viuda de Juan Lacio, a la Enseña del Agricultor, a costa del Autor, 1568. 
Jones, Jr., J. W., «The Allegorical Traditions of the Aeneid», en J. D. Bernard (ed.) Vergil at 2000. Commemorative Essays on the Poet and His Influence, New York, AMS Press, 107-132.

LaRa Garrido, José, Los mejores plectros. Teoría y práctica de la épica culta en el Siglo de Oro, Málaga, Analecta Malacitana, Anejo XXIII, Universidad de Málaga, 1999.

Lawrance, Jeremy, «The Spread of Lay Literacy in Late Medieval Castille», Bulletin of Hispanic Studies, 62 (1985), 79-94.

LAWRANCE, Jeremy, «On Fifteenth-Century Spanish Vernacular Humanism», en Medieval and Renaissance Studies in Honour of R. B. Tate, I. Michael y R. A. Cadwell (eds.), Oxford, The Dolphin Book, 1986, 63-79.

Lawrance, Jeremy N. H., «Humanism in the Iberian Peninsula», en A. Goodman y A. MacKay (eds.), The Impact of Humanism on Western Europe, London \& New York, Longman, 1990, 220-258.

Lerner, Isaías (ed.), Alonso de Ercilla, La Araucana, Madrid, Cátedra, 1993.

Lida de Malkiel, María Rosa, Juan de Mena, poeta del prerrenacimiento español, México, El Colegio de México, 1950, 1984².

Lida de Malkiel, María Rosa, La idea de la fama en la Edad Media castellana, México, FCE, 1952.

Macías Rosendo, Baldomero, «La Vida de Virgilio escrita por Enrique de Villena y sus fuentes», Etiópicas, 2 (2006), 1-7.

Mena, Juan de Las Obras del Famoso Poeta Juan de Mena, nuevamente corregidas y declaradas por el Maestro Francisco Sánchez, Catedrático de Prima de Rhetórica en la Universidad de Salamanca, En Salamanca, en casa de Lucas de Iunta, 1582.

Mena, Juan de, La Yliada en romance según la impresión de Arnao Guillén de Brocar (Valladolid, 1519), M. de Riquer (ed.), 1949.

Mena, Juan de, Laberinto de Fortuna y otros poemas, C. de Nigris (ed.), G. Serés (estudio preliminar), Barcelona, Crítica, Biblioteca Clásica, 1994.

Menéndez Pelayo, Historia de las ideas estéticas en España, Madrid, CSIC, 1946-47.

Miguel Prendes, Sol, El espejo y el piélago. La Eneida castellana de Enrique de Villena, Kassel, Edition Reichenberger, 1998.

Morrás, María, «Un tópico ciceroniano en el debate sobre las armas y las letras", en Literatura medieval. Actas do IV Congresso da Associaçao Hispânica de Literatura Medieval, Ediçoes Cosmos, Lisboa, 1993, vol. IV, 115-122.

Morros, Bienvenido, Las polémicas literarias en la España del siglo XVI: a propósito de Fernando de Herrera y Garcilaso de la Vega, Barcelona, Quaderns Crema, 1998.

Murrin, Michael, The Allegorical Epic. Essays in Its Rise and Decline. Chicago y Londres: The University of Chicago Press, 1980.

Nuñez de Oria, Francisco, Lyrae Heroicae libri quatuordecim, Salmanticae: apud haeredes Mathie Gastij, 1581. 
Núñez de Toledo, Hernán, Comentario a las 'Trescientas' de Hernán Núñez de Toledo, el Comendador griego (1499, 1505), J. Weiss y A. Cortijo Ocaña (eds.), eHumanista. Journal of Iberian Studies. <http://www.ehumanista. ucsb.edu/projects/Weiss\%20Cortijo/index.shtml>

Pérez de GuZmán, vid. Barrio, José Antonio

Pierce, F., La poesía épica del Siglo de Oro, Madrid, Gredos, 1968.

PonTón, Gonzalo, «Un lugar de Séneca en las letras castellanas del siglo XV», Boletín de la Real Academia Española, LXXXI (2001), 159-172.

Pontón, Gonzalo, «Fernando del Pulgar y la Crónica de los Reyes Católicos», prólogo a Fernando del Pulgar, Crónica de los Reyes Católicos, J. de Mata Carriazo (ed.), Granada, Universidad de Granada-Marcial Pons, 2008, vol. I, vii-ciii.

Prieto, Antonio, "Origen y transformación de la épica culta en castellano», Analecta Malacitana, 2 (1979), 193-243.

Quintana, Manuel José, «Sobre la poesía épica castellana», en Biblioteca de Autores Españoles, Obras completas de Don Manuel José Quintana, Madrid, Ediciones Atlas, 1946, 158-173.

Rico, Francisco, Nebrija frente a los bárbaros, Salamanca, Universidad de Salamanca, 1978.

Rico, Francisco, «Petrarca y el 'Humanismo catalán'», en G. Tavani y J. Pinell (eds.), Actes del sisè col-loqui internacional de llengua i literatura catalanes, Roma, 28 setembre - 2 octubre, 1982, Barcelona, Publicacions de l'Abadia de Montserrat, 1983, 17-291.

Rico, Francisco, El sueño del humanismo. De Petrarca a Erasmo, Madrid, Alianza, 1997.

Riquer, Martí de, Aproximació al Tirant lo Blanc, Barcelona, Quaderns Crema, 1990.

Rosell, Cayetano, "Advertencia», en Biblioteca de Autores Españoles, Poemas épicos, vol. 1, Madrid, Ediciones Atlas, 1945, 1-7.

Round, Nicholas G., «Renaissance Culture and its Opponents in FifteenthCentury Castile, Modern Language Review, 57: 2 (1962), 204-215.

Russell, Peter E., «Las armas contra las letras: para una definición del humanismo español del siglo Xv», en Temas de La Celestina y otros estudios. Del Cid al Quijote, Barcelona, Ariel, 1978, 209-239.

Russell, Peter E., Traducciones y traductores en la peninsula ibérica (1400-1550), Bellaterra, Servicio de Publicaciones de la Universitat Autònoma de Barcelona, 1985.

Santiago Lacuesta, Ramón, La primera versión castellana de "La Eneida», de Virgilio, Madrid, Anejos del Boletín de la Real Academia, 1980.

Serés, Guillermo, La traducción en Italia y España durante el siglo XV. La "Ilíada en romance» y su contexto cultural, Salamanca, Ediciones Universidad de Salamanca, 1997.

TATE, Robert B., "La historiografía en la España del siglo XV», en Ensayos sobre la historiografía peninsular del siglo XV, Madrid, Gredos, 1970, 280-296. 
TATE, Robert B., «La historiografía del reinado de los Reyes Católicos», en C. Codoñer y J. A. González Iglesias (eds.), Antonio de Nebrija. Edad Media y Renacimiento, Salamanca, Ediciones Universidad de Salamanca, 1994, 17-28.

ThIlo, Georg y Hagen, Hermann, Servii Grammatici qui feruntur in Vergilii carmina commentarii, 3 vols., Hildesheim, Zürich, New York, Georg Olms Verlag, 1986.

Valbuena Briones, Ángel, «Épica e historia», Archivum, 8 (1958), 83-110.

Valero Moreno, Juan Miguel, «La Expositio Virgilianae de Fulgencio: poética y hermenéutica», Revista de poética medieval, 15 (2005), 112-192.

Vega, María José, «Idea de la épica en la España del Quinientos», en M.J. Vega y L. Vilà (eds.), La teoría de la épica en el siglo XVI (España, Francia, Italia y Portugal), Vigo, Editorial Academia del Hispanismo, 2010, 103-135.

Vega, María José y ViLÀ, Lara (eds.), La teoría de la épica en el siglo XVI (España, Francia, Italia y Portugal), Vigo, Editorial Academia del Hispanismo, 2010.

VILÀ, Lara, Épica e imperio. Imitación virgiliana y propaganda política en la épica española del siglo XVI, Tesis doctoral, Universitat Autònoma de Barcelona, 2001.

VILÀ, Lara, «La épica española del Renacimiento (1540-1605). Propuestas para una revisión", Boletín de la Real Academia Española, tomo LXXXIII, cuaderno CCLXXXVII (enero-junio 2003), 137-150.

VILÀ, Lara, «'Historia verdadera' y propaganda política. La Felicísima victoria de Jerónimo Corte Real y el modelo épico de Virgilio", Res Publica Litterarum. Documentos de trabajo del grupo de investigación "Nomos», Universidad Carlos III de Madrid. 2005-5. D.L.: M-24672-2005. ISSN: 1699-7840. Versión digital: http://docubib.uc3m.es/WORKINGPAPERS/IECSPA/ iecspA050505.pdf

VILÀ, Lara, «Batallas más que pictóricas. Écfrasis e imperialismo en El Monserrate de Cristóbal de Virués», Revista Silva, 4 (2005), 301-327.

VILÀ, Lara, «Reconquista y virgilianismo cristiano», en Lara Vilà y Cesc Esteve, «Estudio preliminar al Pelayo del Pinciano» Alonso López Pinciano, El Pelayo del Pinciano. Madrid, 1605. Madrid-Barcelona, Publicaciones del Seminario de Poética Europea del Renacimiento (UAB) y del Instituto Séneca de la Universidad Carlos III de Madrid. Mirabel Editorial. Bibliotheca Sphaerica, 3. 2005.

VILÀ, Lara, Épica, historia y la construcción de los mitos nacionales. La problemática de la teoría y la praxis de la épica culta en el siglo xvi (en Italia y España)», História \& Perspectivas, 34, vol. 1 (2006), 83-106. (Versión digital: http://www.historiaperspectivas.inhis.ufu.br/viewarticle.php?id=29).

VILÀ, Lara, "Los poemas de la 'fundación' nacional. La épica del siglo XVII y la idea del imperio", Conceptos. Revista de Investigación Graciana, 4 (2008), 53-67.

VILÀ, Lara, «El Carlo Famoso de Luis Zapata. Las "Caroleidas» y la tradición épica», Estudio introductorio a Luis Zapata de Chaves, Carlo Famoso, Be- 
llaterra-Madrid, Seminario de Poética Europea del Renacimiento (UAB) e Instituto Séneca (U. Carlos III de Madrid), 2009, 4-47.

VILÀ, Lara, «Épica y poder en el Renacimiento. Virgilio, la alegoría histórica y la alegoría política», en M. J. Vega y L. Vilà (eds.), La teoría de la épica en el siglo XVI (España, Francia, Italia y Portugal), Vigo, Editorial Academia del Hispanismo, 2010, 23-59.

VILÀ, Lara, "Vera cum fictis. La alegoría histórica serviana y la idea del epos», en M. Bouquet y B. Méniel (eds.), Servius de l'Antiquité à la Renaissance, Rennes, Presses Universitaires de Rennes, 2010 (en prensa).

VIVes, Juan Luis, Antologia de textos, València, Universitat de València, 1992.

WeIss, Julian, The Poet's Art. Literary Theory in Castile c. 1400-60, Oxford, The Society for the Study of Mediæval Languages and Literature, 1990.

WeIss, Julian, «Political commentary: Hernán Nuñez's glosa a 'Las Trescientas'», en A. Deyermond y J. Lawrance (eds.), Letters and Society in Fifteenth-Century Spain. Studies presented to P. E. Russell on his eightieth birthday, Llangrannog, Dolphin Book, 1993, 205-216.

WeIss, Julian, y Cortijo, Antonio (eds.), Comentario a "Las Trescientas» de Hernán Núñez de Toledo, el Comendador Griego (1499, 1505), Journal of Iberian Studies: www.spanport.ucsb.edu/projects/ehumanista/projects/

Zapata, Luis, Carlo Famoso, Valencia, en casa de Juan de Mey, 1566. 